Chicago-Kent College of Law

Scholarly Commons @ IIT Chicago-Kent College of Law

All Faculty Scholarship

Faculty Scholarship

$3-2010$

\title{
Scorn Not the Sonnet: In Search of Shakespeare's Law
}

Jeffrey G. Sherman

IIT Chicago-Kent College of Law, jsherman@kentlaw.iit.edu

Follow this and additional works at: https://scholarship.kentlaw.iit.edu/fac_schol

Part of the Legal Writing and Research Commons

\section{Recommended Citation}

Jeffrey G. Sherman, Scorn Not the Sonnet: In Search of Shakespeare's Law, (2010).

Available at: https://scholarship.kentlaw.iit.edu/fac_schol/563

This Article is brought to you for free and open access by the Faculty Scholarship at Scholarly Commons @ IIT Chicago-Kent College of Law. It has been accepted for inclusion in All Faculty Scholarship by an authorized administrator of Scholarly Commons @ IIT Chicago-Kent College of Law. For more information, please contact jwenger@kentlaw.iit.edu, ebarney@kentlaw.iit.edu. 


\title{
SCORN NOT THE SONNET:
}

\section{IN SEARCH OF SHAKESPEARE'S LAW}

\author{
by \\ Jeffrey G. Sherman* \\ Professor of Law \\ Chicago-Kent College of Law \\ Illinois Institute of Technology
}

*A.B., 1968, J.D., 1972, Harvard 


\section{SCORN NOT THE SONNET: IN SEARCH OF SHAKESPEARE'S LAW ${ }^{1}$}

Legal scholars love Shakespeare. I don't mean simply that we love to quote him. Everyone loves to quote him. ${ }^{2}$ What I mean is that we love to use his works as stimuli and even models for legal analysis. We write about King Lear or The Merchant of Venice but rarely about the Sonnets. ${ }^{3}$ Why is that?

When legal scholars turn to Shakespeare's plays for inspiration, we focus on the plays' content - the division of a kingdom, the enforcement of a contract - and unfortunately the Sonnets, being lyric poetry, have no content: at least not what legal scholars are trained to think of as content. For example, one of Shakespeare's most famous sonnets (the "Fortune and men's eyes" one) can be summed up as, "When I'm feeling depressed, I think about you, and that cheers me up." Another (the "marriage of true minds" one) might easily be reduced to a single one of its tropes: "Love is not love / Which alters when it alteration finds." And each of the first seventeen sonnets seems to be merely a plea to a handsome young man to sire children so that his good looks will not die out with him. How is a legal scholar to find intellectual nourishment in such seemingly insipid fare?

If a scholar probes the Sonnets for autobiographical revelation or social controversy, she can expect to come up empty. ${ }^{4}$ A Shakespeare sonnet is a kind of performance, but a performance in which the actors are not persons but words. ${ }^{5}$ These words perform by elaborating upon themselves (and each other), by contradicting, by equivocating, by mutating, ${ }^{6}$ by ironizing, by punning, by self-regarding, and (sometimes) by rhyming. John Ciardi's famous book-title How Does a Poem Mean? puts the matter elegantly, for a poem does not convey meaning the way prose conveys it. That is, a prose paraphrase of a poem does not mean what the poem means, even if the poem and the paraphrase share the same "propositional content." 7 The meaning of a poem consists in its delivery of meaning. One should regard it as an aesthetic mechanism whose moving parts are words and whose function is to mirror a state of mind. Observing how the machine functions - noting its strategies of presentation - is the poetry-reader 's task and also her reward.

But why sonnets? They amount to only a small share of lyric poetry. It is all very well to say that a lyric poet uses words as actors, but why should he adopt the sonnet form for his performance? Two reasons come to mind. First, a sonnet is a display of technical skill, like a fugue, and writing a sonnet allows the poet to demonstrate his writing chops. The sonnet form is strict and unyielding, comprising fourteen lines of iambic pentameter with one of several rhyme schemes: most often abbaabbacdecde, abbaabbacdcdcd, ababbcbccdcdee, or ababcdcdefefgg (Shakespeare's rhyme scheme). To write graceful, satisfying poetry in such fetters is no easy task. One of Percy Bysshe Shelley's most famous poems, "Ozymandias", is a sonnet, and the very form of the poem contrasts ironically with the vainglory of the poem's long-dead king whose monumental statue now lies in ruins. "Look on my works, ye Mighty, and despair!" reads the inscription on the abandoned pedestal. ${ }^{8}$ "Look on $m y$ works," the sonneteer Shelley seems to reply. "The architecture of the written word outlasts the architecture of stone. The achievements of the human mind surpass the achievements of power." 9

The second reason for writing sonnets is more difficult to put into words but nicely captured by William Wordsworth in a sonnet of his own: "Nuns Fret Not at Their Convent's Narrow Room:"10 
In sundry moods, 'twas pastime to be bound

Within the sonnet's scanty plot of ground;

Pleased if some souls (for such there needs must be)

Who have felt the weight of too much liberty,

Should find brief solace there, as I have found.

To modern ears Wordsworth's "weight of too much liberty" sounds more like the sloganeering of a totalitarian apologist than the ruminating of a romantic poet. But if we allow our imaginations to wander a bit, we can, I think, come to discern the "solace" that restrictions afford. The availability of too many choices can paralyze. When a high school English teacher asks his class to write an essay and his students ask him to specify the subject matter, they are likely to regard " your summer vacation" as a more helpful response than "whatever you want." Visiting a museum with an enormous collection can be overwhelming, while visiting one with a small collection can be reassuring. And a sense of limitation enhances pleasure. A game without rules or boundaries is no game at all. I often think that legal scholars who choose to write about tax law rather than, say, international law have known the solace of which Wordsworth speaks.

I have characterized the Sonnets as intellectual exercises, ${ }^{11}$ but I do not use that phrase disparagingly, for the intellect I am talking about is, after all, Shakespeare's. These poems are not sermons or dissertations written for our improvement; indeed, I cannot think of any literary project more alien to Shakespeare. An account of these Sonnets that fails to embrace their internal shiftings and self-contradictions, but instead attempts to reconcile or excuse them, misses the poems' quality completely and reduces them to pabulum. In his novel Nineteen Eighty-Four, Orwell coined the term "doublethink", meaning the capacity of "holding two contradictory beliefs in one's mind simultaneously, and accepting both of them." $12 \mathrm{He}$ obviously regarded doublethink as unnatural and destructive: something that can flourish only when a totalitarian regime's thought-control techniques successfully destroy our capacity to make reasoned judgments. But to the poet, doublethink can be a gift. John Keats, in a letter to his brothers, coined the term "Negative Capability" to describe a quality that he considered indispensable to a great poet: the "capab[ility] of being in uncertainties, mysteries, doubts, without any irritable reaching after fact and reason."13 And he went on to observe that it was a " quality ... which Shakespeare possessed so enormously." 14 Negative Capability permits its possessor to remain comfortable with the disorder and incongruities of the human condition without striving to impose on them a coherent, unified system of understanding. Yet lawyers strive to do precisely what those with Negative Capability resist. Lawyers do strive to discover or create system. Lawyers are "irrita[ted]" by mystery and do "reach after fact and reason."

Why, then, should lawyers and legal scholars care about Shakespeare at all, given his “ enormous[]" indifference to the certainty and perfection toward which they aspire? Shakespeare' s appeal springs from two elements: the extraordinary breadth and acuity of his sympathies and the extraordinary beauty and power of his language. As to the first, his delicate and forbearing understanding of human motive and serves to remind us that law is directed not at abstractions but at particular, complicated human beings 15 and that justice is not an attainable goal but merely a direction. ${ }^{16}$ As to the second, Shakespeare can teach us to read like lawyers. When writing for the theatre, Shakespeare wrote not to be read but to be heard; and while readers read for "meaning," listeners generally listen merely for "sense." In the theatre, we can still enjoy Portia's bitchy catalog of her unwelcome suitors without knowing quite what she means by

he borrowed a box of the ear of the Englishman, and swore he would pay him again when he was able. I think the Frenchman became his surety and seal'd under for 
another. ${ }^{17}$

But we do not have the same luxury - i.e., attending only to "sense" - with the Sonnets. Shakespeare, "the most hyperconscious of writers," 18 wrote them to be read, and so in a sonnet's 140 syllables every word must signify. ${ }^{19}$ And lawyers are at least supposed to read the way sonnets are supposed to be read: Every pronoun must be satisfactorily linked in the reader's mind with the pronoun's antecedent; ${ }^{20}$ every shift in number or tense must be digested. In other words, the Sonnets can teach lawyers to read and think closely, the way lawyers ought to read and think.

In this article, I propose to examine three of Shakespeare's sonnets and illustrate how a legal scholar or law professor might use these sonnets as scholarly or pedagogical vehicles. These illustrations will not discuss legal issues to a point of conclusion but will simply present some legal issues as analytic opportunities offered by a close reading of the Sonnets.

\section{Sonnet 35}

Let us begin with a sonnet that seems rather surprisingly to take much of its imagery from the law. In it, we find legalistic phrases like adverse party and lawful plea as well as lay words clearly freighted with specialized legal meaning: authorizing, trespass, fault, advocate, accessary. ${ }^{21}$ Sonnet 35 is one of the so-called Young Man sonnets, wherein the speaker addresses his beloved: a young man of extraordinary physical beauty but somewhat questionable virtue and fidelity.

$1^{22}$ No more be grieved at that which thou hast done:

2Roses have thorns, and silver fountains mud, 3 Clouds and eclipses stain both moon and sun,

4And loathsome canker lives in sweetest bud.

5All men make faults, and even I in this, 6Authórizing thy trespass with compare, $7 \mathrm{My}$ self corrupting salving thy amiss, 8 Excusing thy sins more than thy sins are; 9 For to thy sensual fault I bring in sense 10Thy adverse party is thy advocate 11 And 'gainst myself a lawful plea commence. 12Such civil war is in my love and hate

13 That I an áccessary needs must be

14 To that sweet thief which sourly robs from me.

Lines 2-4 comprise a series of platitudes about the flaws that inhere in beautiful things, and Line 1 suggests strongly that these platitudes are addressed by the speaker to his beloved. Evidently, the speaker had on previous occasions reproached the beloved for his conduct (that which thou has done), and evidently those reproaches hit home. But in this first quatrain the speaker tells the beloved not to feel ashamed any more (No more be grieved), because it is only natural that the beloved - being a thing of beauty, like a rose - should have his thorns. But the speaker's platitudes in this first quatrain grow progressively more bitter. A lover might not feel stung when told that he is a rose with thorns, but he is likely to feel crushed when told that he has a disgusting canker worm inside him, even if sweetest somewhat softens the blow by suggesting that cankers always choose the sweetest flowers as their victim. ${ }^{23}$ Furthermore, the connotations of the two images are quite different. A rose's thorns do not undermine the rose, 
while a canker certainly does undermine its host. One senses that the speaker, in offering these mitigative bromides to his lover, is not being entirely genuine when he protests that he wants his lover to cease grieving.

The rhyme scheme of the first quatrain is the rhyme scheme Shakespeare used in all his sonnets: $a b a b$. Yet when the quatrain is read aloud, all four lines are revealed to feature the same vowel sound: $\breve{\mathrm{u}}$ (the short $u$ ). Done, Mud, Sun, Bud. This effect is known as a vowel rhyme, 24 and as used in this sonnet it gives the four lines a weary, monotonic sound, as if the speaker is reciting the words by rote rather than speaking from his heart. Thus, the very sound of the lines reinforces our impression that the speaker's words so far are not to be taken at face value. ${ }^{25}$

The next quatrain represents a complete change in tone, but in fact it helps to explain our reaction to the first quatrain. In the second quatrain, the speaker finally starts to speak about himself instead of in abstractions. After acknowledging that all men commit sins (make faults), the speaker says that he himself (even I) has sinned. The speaker's sin, says he, consists in his having justified or excused (authoriz[ed]) his beloved's misconduct. Presumably, this justifying or excusing often took the form of citing - either to himself or to his beloved - those mitigative platitudes with which the sonnet begins. Thus, the platitudes in the first quatrain are now, in the second quatrain, being recalled or quoted with some bitterness by the speaker: recalled now as earlier manifestations of the speaker's own sin. Perhaps in that earlier time, the speaker spoke to his beloved less bitterly (i.e., nothing about cankers) and more sincerely (no vowel rhymes) than his recollections suggest. He tells us in line 12 that feelings of love and hate struggle within him; so perhaps love was in the ascendancy when the speaker originally uttered some mitigative sentiments, and only now, when hate is in the ascendancy, does the speaker's memory sabotage those earlier remarks to the beloved.

In lines 6-8, the speaker reels off his own sins as a catalog of present participles: Authorizing thy trespass, salving thy amiss, ${ }^{26}$ Excusing thy sins. But the overall meaning of line 8 is somewhat obscure. $^{27}$ I read it this way: the speaker is saying that he enlisted his excuse-making powers so profligately and sophistically on behalf of his beloved that the speaker's excuse-making would have sufficed to pardon sins even more serious (or more numerous) than those the beloved actually committed. The very excessiveness of the speaker's excuse-making may even have been a greater sin than the beloved's sins being excused. In other words, the speaker has not merely forgiven the beloved's sins. That would be nothing to be ashamed of. The speaker laments that he has gone beyond mere forgiveness and has entered the domain of complicity. ${ }^{28}$ That is, he did not see his lover's misdeeds for what they were at the time the lover committed them but then, out of love, gone on to forgive the lover's misdeeds. Rather, he allowed his feelings of love to cause him to overlook the misdeeds when they occurred. Instead of saying to himself, "That's a misdeed, but I forgive it," the speaker said to himself, "That's not a misdeed at all, so there's nothing to forgive."

Among the three present participles in the speaker's catalog of his own sins lies a fourth present participle, corrupting (line 7), but this fourth participle is a changeling. It applies not to the conscious acts of the speaker (authorizing, salving, excusing) but to the consequences of those conscious acts. All that authorizing, salving, and excusing on behalf of the beloved has had the effect of corrupting the speaker: specifically, corrupting the speaker's self. In line 7, the speaker does not use the word "myself" in line 7; he uses the two words my self. The single word "myself " is just a fancy substitute for "me", but the two words my self posit the existence of something fundamental but separable from the human organism that is the speaker. Thus, the speaker accuses himself of betraying his very personhood. 
The last six lines (or "sestet") of this sonnet contain almost all of the poem's legal imagery. Now critics seldom speak of a sestet in the context of a Shakespeare sonnet. Most Shakespeare sonnets comprise three quatrains of more-or-less equal thematic weight (the last of which ends with a period), followed by a couplet: a new sentence, more pointed and less allusive than any of the preceding sentences, that the reader experiences as a resolution of the sonnet's action. 29 Thus, inasmuch as the final couplet does not relate particularly to the third quatrain any more than to the first or second, the reader of a Shakespeare sonnet rarely experiences the last six lines as a unit. 30 But the last six lines of this Sonnet 35 are very different. From adverse party to internal civil war to out-and-out accomplice (accessary), the ferocity of the speaker's self-reproach gathers such momentum that ultimately it bursts the bonds of the last quatrain and overruns the couplet as well.

In the sestet's first line, we learn that the beloved's misconduct was sexual (sensual ${ }^{31}$ ) in nature - perhaps promiscuity, perhaps sexual betrayal (sleeping with the speaker's mistress 32 ) - and that the speaker's reaction to that sexual misconduct was not the emotional or visceral response we might expect but rather an intellectual one (I bring in sense). 33 Even though the speaker is the injured party - the plaintiff, as it were - he enlists his intellect to justify the beloved's injurious conduct to him, just as if he were the defendant-beloved's lawyer in a lawsuit brought by himself (Thy adverse party is thy advocate [line 10]). Indeed, he goes beyond acting as the defendant's lawyer and becomes his own prosecutor ('gainst myself a lawful plea commence [line 11]), ${ }^{34}$ presumably for the offense of authorizing, salving, and excusing (lines 6-8) the beloved when he should instead have been honoring his own true nature and interests. Moreover, he enters this self-condemning plea on compulsion (I . . needs must [line 13]), not by choice. And the source of the speaker's compulsion is perhaps the violence of his conflicted feelings (civil war . . in my love and hate [line 12]): love for his beloved coupled with hate for the man who sourly robs [line 14] him of his self. [line 7]. 35

Let us turn now to an examination of the ways in which a law scholar or teacher might use this sonnet as a jumping-off point for her projects.

$$
\text { a. My self }
$$

The notion of an essential self separable from the human organism containing it figures prominently in a pair of conversations central to Robert Bolt's splendid play A Man for All Seasons. Sir Thomas More and the Duke of Norfolk are discussing More's refusal to ratify King Henry's arrogation of the office of head of the Church in England in contravention of the Roman Catholic doctrine of the apostolic succession of the Pope. 36 Norfolk dismisses the doctrine as a mere "theory" and asks More how he can justify throwing away his position and even his life in defense of it. More replies:

[I]t's a theory, yes. ... But what matters to me is not whether it's true or not but that I believe it to be true, or rather not that I believe it but that $I$ believe it. . . I will not give in because I oppose it - I do - not my pride, not my spleen, nor any other of my appetites, but $I$ do $-I$.

In the same way, the speaker in Sonnet 35 might have said, "My sin consisted not in my having corrupted myself but in my having corrupted my self."

But loyalty to one's essential self is not necessarily admirable. What despot or bigot or bully or 
scoundrel could not accurately say along with Thomas More, "But what matters to me is not whether it's true or not but that I believe it to be true"? 38 What unashamed segregationist or killer of abortion-providers could not accurately say along with More, "I will not give in because I oppose it $-I$ do - not my pride not my spleen, nor any other of my appetites, but $I$ do $-I "$ ?"39 As private citizens we may, from a philosophical or aesthetic standpoint, applaud the courage and self-reliance of such recusants, but as a civil society of laws can we afford to treat the mere sincerity and vehemence of a person's beliefs as justification for her violation of those laws? Until we can trust those laws to distinguish among Antigone before Creon, Luther before the Diet of Worms, and George Wallace crying "Segregation Forever" before the doors of the Alabama state capitol, perhaps the safer answer to that question is no.

One branch of legal doctrine, however, answers that question in the affirmative: the doctrine of conscientious objection to military conscription. A man claiming an exemption on such grounds is, in effect, asserting his self. In a statutory construction case, Welsh v. United States, 40 which involved a statutory exemption for men whose objections to military service were founded on " religious training and belief" as distinguished from "political, sociological, or philosophic views, or a merely personal moral code," 41 the United States Supreme Court held that even a man who disavowed belief in any acknowledged religion could qualify for the exemption. The Court supported its decision by noting that the petitioner was responding not to the "still, small voice of conscience" but rather to a voice that was "loud and insistent;" 42 that his beliefs were "held with the strength of traditional religious convictions; ${ }^{43}$ and that they did not rest upon "considerations of policy, pragmatism or expediency." 44 Or, to use Thomas More's words, they did not rest upon "my pride, .. . my spleen, [or] any other of my appetites." 45

This self of which the sonnet's speaker is so solicitous is not a unitary self; it is conflicted. It loves and it hates simultaneously. Yet some legal rules are premised unrealistically on the existence of unmixed motives. Suppose a father bequeaths to his daughter a life estate in trust but provides that the daughter will receive the trust property outright if she and her current husband divorce. Some courts have held that if the divorce condition was motivated by the father's desire to encourage the daughter to divorce her husband, the condition is void on public policy grounds, and the daughter will receive the property outright immediately. But if the condition was motivated by a desire to provide extra property for the daughter in the event the principal breadwinner ceased to be obligated to support her, the condition is valid. ${ }^{46}$ I have argued elsewhere that a testator's motive should be irrelevant in determining the validity of a testamentary condition. ${ }^{47}$ Here I would simply call attention to Sonnet 35 's warning that we are complicated creatures with complicated motives; the testator in my example might conceivably have had two motives: encouraging divorce and protecting his daughter against impoverishment.

\section{b. Compare}

Shakespeare's speaker in the sonnet includes among his sins Authorizing thy trespass with compare: that is, justifying the beloved's misdeeds by comparing them with other misdeeds and finding the former to be less serious. ${ }^{48}$ This form of justification is disingenuous and corrupt. One can always envisage a crime more serious than the one under examination, so by the logic of this comparative approach to culpability every crime should be excused and nothing is forbidden. Sometimes the comparative approach is relatively harmless, as when a driver stopped for speeding rebukes the police officer, "Why aren't you out catching murderers?" But sometimes this approach is put to more destructive uses. When news surfaced of Atlanta Falcons quarterback Michael Vick's likely involvement in a dog-fighting ring, defenders and spin-doctors 
argued that the vehemence of the widespread condemnation of Vick was misplaced because, they said (in effect), "It's just dogs. It's not as if he had beaten his wife or driven while intoxicated." 49 If Vick had beaten his wife, imagine our outrage if his defenders had argued, "It was just a beating. It's not as if he actually killed her."

Sometimes defenders and spin-doctors use deliberately false comparisons as a way of minimizing an offense. For example, at about the same time as the Vick affair the University of California at Irvine offered the deanship of its new law school to a well-known liberal scholar, Erwin Chemerinsky. A week later, the University withdrew the offer on the ground that Chemerinsky was "too politically controversial." 50 When the withdrawal provoked almost universal cries of outrage from "legal scholars across the political spectrum," 51 the University rescinded its rescission and Chemerinsky accepted the offer. Shortly thereafter, the University's chancellor, who earlier had personally flown to Chemerinsky's home to withdraw the offer, dismissed concerns that the contentiousness of the hiring process might have profound implications for the University by saying "Every relationship has bumps," 52 as if the turmoil had been a romantic spat instead of a battle for the soul of an institution and as if withdrawing an offer for political reasons were an unremarkable misunderstanding to which all universities are a party at one time or another.

While comparisons sometimes mislead, one special kind of comparison - the analogy - can sometimes illuminate. The United States military's longstanding administrative ban on gay people in the armed forces was given statutory form in 1993 as a compromise policy popularly known as "don't ask; don't tell." 53 Under this policy, the military was instructed not to inquire into a soldier's sexual orientation, so a discreet gay person was permitted to serve; but once that soldier "openly and avowedly" declared his homosexuality, the military was instructed to discharge him. This amended policy, targeting only known gay people, made explicit what had been merely implicit before: that the military seeks to exclude gay people not because it thinks they make bad soldiers but because it is afraid nongay soldiers will hate them once they learn of their sexual orientation. ${ }^{54}$ Speaking against allowing gay people in the armed services, a representative of the Non-Commissioned Officers Association warned that the presence of gay people would hurt other soldiers' morale:

Morale in the armed forces is a fragile asset. It can be instantly destroyed even by those acting with the best intentions. History has proven that the degradation of morale quickly leads to the erosion of discipline, diminished performance, poor retention, readiness reduction and recruiting difficulties. NCOA submits ... that any change in [the military's anti-gay] policy will most assuredly have identical results. . . I cannot think of a better way to destroy fighting spirit and gut U.S. combat morale. 55

This argument is the same kind of blame-the-victim argument used in the 1930s and 1940s to justify separating African-American soldiers from other soldiers. Indeed, opponents of racial integration in the military used almost the same words later used to oppose a gay presence in the military:

The close and intimate conditions of life aboard ship, the necessity for the highest possible degree of unity and esprit-de-corps; the requirement of morale - all these demand that nothing be done which may adversely affect the situation. Past experience has shown irrefutably that the enlistment of Negroes (other than for mess attendants) leads to disruptive and undermining conditions. 56 
To me, the analogy is a strong one and a useful way of showing opponents of gays in the military how wrongheaded their arguments are. Both the anti-black exclusion in the 1940s and the anti-gay exclusion in the 1990s derive from "popular prejudices, nourished by deeply entrenched mythologies." 57 Both impose the costs of prejudice on the victims of prejudice. Both presuppose that the best response to hatred is to shut out the hated. 58

Yet when this analogic argument is presented on behalf of gay people wishing to serve, some African-American leaders reject the analogy by saying that race, unlike homosexuality, is a " benign" characteristic without "behavioral" ramifications, 59 the implication being that while aversion to black people is unjustified, aversion to gay people is not. Such objections sadly ignore the historical fact that blackness was not always regarded as a benign characteristic and that aversion to gay people is defended with the same kind of language once used to justify aversion to black people, including the canard that they cannot control their sexual impulses. 60 But as a matter of strict logic, the objection does undermine the persuasiveness of the analogic argument; for if the hatred of gay people and the hatred of black people are not analogous, the argument collapses.

Surprisingly, though, those who reject the analogy argue not simply that it is logically unsound but that it is insulting to black people. "[T]o lump blacks with homosexuals," wrote one commentator, "is an affront to most African Americans." 61 The insult, according to such critics, consists in the unfounded assumption that the suffering of gay people at the hands of the heterosexual majority has been equal - in both intensity and iniquity - to the suffering of black people at the hands of the white majority, whereas in fact (say such critics) black oppression has been worse than gay oppression. 62 This kind of compare - to use Sonnet 35's word - troubles me greatly because it assumes that reform is a zero-sum game, that degrees of oppression can be calibrated, and that only the most demonstrably oppressed group is morally entitled to demand justice. African-American journalist Clarence Page calls this argument "one-downs-manship,"63 and it can undermine the aspirations of the very people who use it, allowing their adverse part[ies] (the Sonnet's words again) to stand back and watch. When black people and gay people argue about which group has been more victimized, the only people who benefit from the controversy are people who are neither black nor gay. When black people and women argue about which group has been more oppressed, 64 the only people who benefit are those who are neither black nor female.

Despite the objections to compare[s], neither the poet nor the lawyer can do without them. The most common poetic figures of speech - similes and metaphors - are comparisons, and Sonnet 35 relies heavily upon them. Although the speaker, in the second quatrain, retrospectively rejects the comparisons he had previously made, he goes on in the sestet to construct an elaborate lattice of fresh metaphors comparing his conduct to that of parties to a lawsuit. And while Shakespeare, on other occasions, mocks grandiloquent hyperboles, 65 in line 12 he employs one humdinger of a hyperbole: one to which a soldier wounded at Antietem or Gettysburg might take exception. Lawyers, too, would be lost without compare[s]. The very notion of precedent recognizes that while two sets of facts are never identical, they may nonetheless be compar [able].

\section{c. The Plasticity of Words}

Shakespeare frequently reshapes nouns into verbs, 66 but an artist of his range and genius is granted a certain degree of license in the anthimeria department. 67 When the more ordinary among us make the same attempt, the results are rarely felicitous. When Margaret Mitchell, in 
her novel Gone with the Wind, put the phrase "birthin' babies" into the mouth of one of her characters, she intended her readers to take this mutation of the noun "birth" as a solecism delineative of the enslaved teen-ager who uttered it. 68 But by some perverse corollary of Gresham's Law, this solecism has now become chic, and today one frequently finds the directors of what might be called "birth centers" christening their facilities - with considerable self-satisfaction - "birthing centers," 69 perhaps to suggest a primordial connectedness with Mother Earth.

Sometimes, however, this kind of anthimeria reflects not ignorance or pomposity but a happy rethinking of an old concept. I have in mind using the word "lawyer" as a verb: not, as it once was, as a disparaging term meaning "to subject (someone) to the ministrations of a lawyer" (as in "I've been lawyered to death"), but rather as an impersonal term meaning "to perform the functions of a lawyer." I first encountered this usage (in the form of a gerund) in the title of the late Gary Bellow and Bea Molton's book The Lawyering Process, 70 and the usage may have revolutionized - or at least assisted in revolutionizing - legal education. Traditionally, a lawyer' s quality was thought to be simply a matter of knowledge and judgment, the first of which could be acquired in law school and the second in practice. But the new gerund "lawyering" suggests that a lawyer's quality is also a matter of technique. And the technique of lawyering, like all other techniques, is also something that can be acquired in school. This new understanding of technique has led to a profusion of "skills" courses such as negotiation and trial practice. Although considerable disagreement still exists among legal educators as to the amount of skills instruction that law students should receive, there is widespread agreement that they should receive at least some. The coining of "lawyering" has created an educational specialty. Life imitates art.

Another noun-to-verb transformation has produced mixed results: the verb "parent" and its gerund, "parenting". 71 The popularization of "parenting" usefully informs parents that raising a child, like practicing law, is in part a matter of skill - skill that can be acquired - and it reminds them of the enormous formative influence that they exert over their progeny. This is all to the good. But it can also engender in parents a paralyzing self-consciousness, leading them to regard every burp or diaper-change as a turning point of Sophoclean portentousness. Doctor Spock's best-selling book Baby and Child Care, on which Baby Boomers' parents famously relied, began with the reassuring sentence, "You know more than you think you do,"72 encouraging new parents to trust their instincts and to approach the task before them without undue anxiety. But the more recent explosion of "parenting classes" and "parenting manuals" may induce parents to view their children as alarmingly fragile laboratory specimens that must be cosseted and indulged lest the parents receive a failing grade. Or it can encourage parental narcissism and self-congratulation. 73 Sometimes this narcissism is relatively benign, as when parents bestow on their children quirky first names calling attention to the parents' cleverness and individuality. But sometimes it can encourage parents to view their children not as distinct individuals in their own right but rather as flauntable manifestations of their parental skills, leading them to treat the children as means rather than as ends by overloading the children with structure, accomplishments, and anxiety.

Overparented children typically face not just a heavy academic schedule but also a strenuous program of extracurricular activities - tennis lessons, Mandarin classes, ballet. After-school activities are thought to impress college admissions officers. ... When summer comes, the child is often sent to a special-skills camp. Extracurricular activities and camps are areas where competition between parents, thought to be a major culprit in this whole business, is likely to surface. How do you explain to the other mother that 
while her child spent the summer examining mollusks at marine-biology camp, yours was at a regular old camp, stringing beads and eating s'mores? 74

\section{d. [S]ensual vs. [S]ense}

In lines 5 through 9, the speaker suggests that sins of the mind are more blameworthy than sins of the flesh: that transgressors impelled by intellect are more culpable than those impelled by emotion. This hierarchy of blame finds obvious confirmation in our criminal law, which treats one who kills intentionally in cold blood more harshly than one who kills intentionally in the heat of passion. 75 Of course, the mere fact that a heat of passion precipitated the homicide cannot be allowed to mitigate the offense; otherwise, those with less self-control would be rewarded with greater access to the shelter of this legal mitigation. For an intentional killer to be charged only with manslaughter rather than with murder, more is required than mere heat of passion; the passion must have resulted from "adequate provocation."76

The inquiry as to the adequacy of a putative provocation is not a blame-the-victim inquiry. That is, a finding that the provocation is adequate does not imply that the victim is somehow to blame for his own death. The notion, rather, is that the killer's loss of self-control resulting from the provocation is not an entirely unexpected loss of self-control. Provocation is considered adequate if it "might render ordinary men, of fair average disposition, liable to act rashly or without due deliberation or reflection, and from passion rather than judgment."77 One might say that the provocation must have diminished the killer's capacity, albeit only partially and only temporarily. Professor Dressler puts the matter this way:

[The mitigative principle of] provocation . . . is based to a considerable extent on the law's concession to ordinary human frailty; the ultimate question, therefore, is whether we (or the jury) consider the provoked party's anger within the range of expected human responses to the provocative situation. Put somewhat differently, we must decide if the provocative even might cause an ordinary person - one of ordinary and neither short nor saintly temperament - to become enraged or emotionally overcome. 78

The kind of offense mitigated by this rule is an offense of emotion: "to become enraged or emotionally overcome." But if the expectedness of a loss of self-control is the rationale for this mitigative rule, why is emotion the only expected response that can justify mitigation? Cannot intellectualizing - even premeditating 79 - likewise lie beyond the control of the intellectualizer? The speaker in Sonnet 35 asserts that his conflicted emotional state "provoked" his intellectualizing on behalf of his beloved - his authorizing and his bringing in sense - to such an extent that such intellectualizing lay beyond his powers of self-control: (I . . needs must [line 13]). And the Freudians surely teach us that seemingly unemotional mental processes can in fact be driven by feelings of anger or shame which, though only subconsciously experienced, are no less powerful in undermining self-control than the manifest rage felt by, say, a husband upon discovering his wife in the act of adultery. 80 After Freud, can we justifiably distinguish between thinking and feeling? Even John Milton, writing more than 300 years ago, understood that :

The mind is its own place, and in itself

Can make a heaven of hell, a hell of heaven. 81

And as the speaker in Sonnet 35 troubles to remind us, sensual and sense share the same root. 


\section{e. I bring in sense... 'gainst myself}

The speaker asserts that to use one's intellect on behalf of an advers[ary] is corrupting. When an attorney undertakes to represent in court a client whose views or actions she detests, 82 is she not, in a sense, acting 'gainst [her]self? And if so, is she corrupt[ed] in the process? An attorney might choose to represent a detested client out of a sense of loyalty to the adversary system or as an intellectual challenge. But at what cost to the attorney herself? To succeed in such representation, the attorney must compartmentalize her life and detach herself from her own feelings. Having thus detached herself, she may be unable to reconnect with her feelings in domestic or romantic relationships that demand emotional connection. She may be wary and adroit where she would be better served by being open and guileless. "Why Lawyers Lose in Love" is the telling headline for an article in the American Bar Association Journal describing the particular troubles that attorneys may engender when they bring their lawyering skills into the home. 83

\section{Sonnet 138}

This poem is one of the so-called Dark Lady sonnets: a sequence of sonnets about the speaker's mistress, ${ }^{84}$ who, contrary to the standards of beauty prevailing in Shakespeare's England, has black hair and black eyes. 85

1When my love swears that she is made of truth, 2I do believe her though I know she lies, 3That she might think me some untutored youth, 4 Unlearnèd in the world's false subtleties.

5Thus vainly thinking that she thinks me young, 6Although she knows my days are past the best, 7Simply I credit her false-speaking tongue:

8 On both sides thus is simple truth suppressed.

9But wherefore says she not she is unjust?

10And wherefore say not I that I am old?

110 love's best habit is in seeming trust, 12And age in love loves not to have years told.

13 Therefore I lie with her, and she with me,

$14 \quad$ And in our faults by lies we flattered be.

While the speaker in Sonnet 35 was directly addressing his beloved, the speaker in this sonnet is speaking about his beloved; the addressee is seemingly the reader or the speaker himself. And while Sonnet 35 begins with direct discourse - words actually uttered (or recalled as having been uttered) - this sonnet begins with indirect discourse. That is, line 1 does not tell us that the mistress actually uttered the words "I am made of truth." Rather, the speaker simply reports that the mistress said in substance that she was made of truth, but he withholds from us the mistress's actual words. Indeed, the whole sonnet is, in this manner, indirect. Whereas second-person pronouns dominate Sonnet 35 (thou and thy appear in it a total of eight times), this sonnet is dominated by third-person pronouns (she and her appear a total of eleven times). Also, the tone of this sonnet is very different. While Sonnet 35 is grim and accusatory, this sonnet is ironic and tolerant.

In another respect, however, this sonnet is similar to Sonnet 35. Both sonnets begin by referring 
to past acts. The first line of Sonnet 35 suggests (with its no more) that the beloved had grieved over his previous conduct toward the speaker. The first line of Sonnet 138 suggests, inasmuch as one does not ordinarily protest that one is faithful unless one's fidelity has been questioned, that the speaker had previously accused his mistress of infidelity. In this case, the mistress's response to the accusation was to declare that she was made of truth: "truth" in the sense of sexual fidelity. 86 But made of truth is such an extravagant claim - no one is made of truth; no one is entirely honest - that one cannot help suspecting that she protests too much and is in fact guilty as charged. We must remember, though, that these words are the speaker's rendering. Perhaps the mistress's actual words were more believable but the speaker, who know [s] she lies (line 2), recasts the actual words into a seemingly dishonest form.

In line 2, the speaker seems to contradict himself. He says that he believes his mistress's protestations and then says that he knows she is lying. How can that be? One might read this line simply as a pleasing paradox, since one certainly can believe and disbelieve at the same time. 87 But the quatrain as a whole suggests a different reading. When the speaker says $I$. . believe her, what he means is that he pretends to believe her and acts as though he believes her, and in lines 3 and 4 he explains why he pretends: He wants his mistress to think him younger than he really is, lest he lose her love (or at least her sexual accessibility), so he tries to exhibit the naivte and credulousness of an untutored youth. Oddly, however, the speaker, in describing the impression he wishes to create, avoids the expected direct adjectives - "naive" or "ignorant", for example - and instead makes his point indirectly by relying on negative adjectives:

untutored and unlearnèd. 88 This choice enables the speaker - in a way that "naive" and " ignorant" do not - to voice and thereby admit to the very qualities he possesses but wishes to conceal from his mistress: "tutored" and "learnèd".

Reading the first quatrain, we may well wonder whether the mistress is taken in by the speaker's dissimulation. The second quatrain tells us that she is not taken in and, indeed, that she engages in some dissimulation of her own. The speaker would like to believe that his deception succeeds and that the mistress truly thinks [him] young (line 5), but the speaker admits, by inserting the word vainly (in the sense of "futilely"), that he knows in his heart that the deception does not succeed. 89 And in line 6 he comes right out and says she knows that he is old. Well actually, he does not come right out and say "old" (not yet, anyway); he says instead my days are past the best. This arch phrase is a litotes: a rhetorical device whereby an affirmative is expressed by negating its opposite. 90 We say "not bad" to indicate "rather good." When Eleanor Roosevelt, addressing the 1940 Democratic Presidential Convention, declared, "This is no ordinary time," she was admonishing the delegates to recognize how extraordinary the time was. ${ }^{91}$ And Shakespeare himself seems to have coined the litotes "seen better days". 92 Thus, while the sonnet's speaker attributes to his mistress the language of overstatement (made of truth), the speaker himself relies on a mischievous kind of understatement to describe his own circumstances, 93 perhaps flattering himself that he is more self-aware than she.

Line 7 begins with the adverb [s] imply, which euphoniously echoes the adverb vainly in line 5. But while the adverb (meaning "futilely") in line 5 describes the speaker's attempt to fool himself, the adverb (meaning "in pretended simplicity") in line 7 describes the speaker's attempt to fool the mistress: the same attempt to which the previous quatrain is devoted. Indeed, line 7 substantially repeats the remark made in line 2 - "I pretend to believe her even though I know she is lying" - but with a critical difference. In line 7, the speaker does not use the verb believe; he uses the verb credit. That word has undeniable associations with business transactions: e.g., to extend credit (noun) to a would-be purchaser, or to credit (verb) a customer's account for 
returned merchandise. And the next line reinforces the association with commerce by the rather unexpected phrase both sides. What makes the phrase unexpected is that the word sides usually implies the existence of a bargain or a contest, yet here it refers to the speaker and his mistress. The speaker thus likens his and his mistress's mutual amorous relations to mutual contractual relations. He pretends to believe the mistress's lies (about her fidelity) in exchange for her pretending to believe his lies (about his age). Neither side is fooled by these lies, and the word suppressed emphasizes that the lovers' disregard of the truth reflects an act of will, not passive inattention. 94

The adjective simple in line 8 appears to echo the adverb [s]imply in line 7, but this verbal metamorphosis represents a change in connotation. The adverb in line 7 means "in pretended simplicity" - i.e., "as a simpleton might" - while the adjective in line 8 has the same adjectival meaning that we would give it today: uncomplicated, unmistakable. Thus, in line 8 the speaker uses simpl[icity] as a term of praise and in line 7 as a term of disparagement, illustrating perhaps the porousness of the boundary between admirable qualities and unappealing ones. 95

In lines 9 and 10 we reach the climax of the sonnet. With two simple questions, and with the blunt adjective old replacing the evasive phrase past the best, the speaker confronts the two mutual pretenses and asks why. "Why doesn't she just admit to me that she's unfaithful [line 9]? Why don't I just acknowledge to her that I'm old [line 10]?" But the speaker already knows the answers to his two questions, and he supplies them. "The reason she doesn't admit to me that she 's unfaithful is that love's best habit is in seeming trust: she knows that love is more likely to flourish when the parties at least act as though they trust each other. ${ }^{96}$ And the reason I don't admit to her that I am old is that age in love loves not to have years told: older lovers fear that emphasizing their true age will cost them their continued sexual access."

The most distinctive feature of line 12 is the playful word-pair love loves. I have already noted Shakespeare's device of using the same word twice in the same sentence: once in its normal part of speech and once in an unconventional part of speech. ${ }^{97}$ In line 12, however, both uses of the word love - as noun and as verb - are quite conventional. But by putting conventional noun and conventional verb together, the speaker emphasizes the variability of the word and, by extension, the variability of love itself. Indeed, love appears four times in this sonnet, each time with a different meaning, as if to suggest that love itself may take many forms, including a relationship based on mutual pretense such as that described and experienced by the speaker. 98 And in line 12 , the speaker once again uses a deflective litotes (loves not instead of "hates") when referring to himself, just as he did in lines 3,4 , and 6 .

This third quatrain asks two questions and provides two answers, yet each answer is separated from the question to which it responds. A more natural organization would have placed each answer immediately following its question:

9First question [But wherefore says she not ... ]

10Answer to first question [O love's best habit ... ]

11 Second question [And wherefore say not $I \ldots$ ]

12Answer to second question [And age in love... ]

Why does the speaker follow an "unnatural" organization here, putting the two questions together at the beginning and then putting the two answers together at the end? The unlikely line-order sets a trap for his readers: a trap that emphasizes the speaker's untroubled acquiescence in the counterfeit status quo. By the time we reach the third quatrain, the speaker has already described his relationship as one of mutual pretense. Consequently, when we first read the two questions 
together, we are inclined to suppose them rhetorical and expect them to be followed by a renunciation of pretense on both sides and a call for greater honesty: "Why do we tell each other these obvious lies? Why don't we just admit the truth and continue our relationship on a more honest footing?" But, surprise! The speaker does not reject mutual deception; he embraces it. He disappoints our expectations by treating the two questions not as rhetorical but as genuine interrogatories and then answering each of them with an unapologetic call for further deception. Had the quatrain been organized in the more logical question/answer/question/answer format instead of the question/question/answer/answer format, we should have had no time to fall into the trap the speaker laid for us, and we therefore might not have observed the remarkable equanimity with which the speaker accepts this contractual mutual pretense. 99

The couplet resolves the sonnet's action by summarizing the provisions of the couple's bargain and - with a lighthearted sexual pun on the word lie - specifying the nature of the prize derived from the bargain. But lie is not the only pun to be found in the couplet. [F]aults in line 14 is an almost perfect homonym for false, 100 the adjective the speaker uses in line 4 to describe the world's subtleties: what we call in cliché language "the way of the world." The couple, at the last, has fashioned a bargain based on the very subtleties in which the speaker affected to be unlearnèd. And after 13 lines in which all the pronouns were singular, the speaker finally notes in line 14 the mutuality of the pretense by using the plural pronouns our and we. 101

\section{a. Legalese}

Taken as a whole, Sonnet 138 is much easier to understand than Sonnet 35. The earlier sonnet (sequenced earlier; not necessarily written earlier) relies almost entirely on metaphors for its action; the later sonnet uses no metaphors at all.102 And the later sonnet is largely monosyllabic; though both sonnets contain the same number of syllables (140), the later sonnet contains 101 monosyllabic words, while the earlier sonnet contains only 82. The speaker of the later sonnet conspicuously avoids "[t]affeta phrases, silken terms . . ., / Three-piled hyperboles, spruce affectation," 103 and instead confines himself to "russet [homespun] yeas and honest kersey [plain] noes."104 Yet this self-consciously ordinary language is used to describe a contract! When lawyers draft contracts (or statutes or regulations), we tend to employ a complex writing-style known disparagingly as legalese. A critic of legalese might therefore say, "If Shakespeare can express contractual terms simply, why can't you lawyers?" So I should like to take this opportunity to say a few words in defense of legalese.

Every profession has its jargon, and lawyers' jargon is more benign than most. Physicians talk about "contusions" when they could easily say "bruises." I have heard interior architects speak of a "task light" when they meant nothing more remarkable than a "desk lamp." And government officials say "inappropriate" when they want to avoid saying what their objection is. But lawyers ' jargon is designed for exactitude and concision. Common synonyms do not exist for legal terms like "per stirpes" or "consideration" or "impleader", and accordingly these terms of art cannot be replaced except by paragraph-long explications that would make legal texts cluttered and infelicitous.

But it is not lawyers' vocabulary that draws the laity's ire so much as it is our sentence-structure. "Needlessly complicated" is a common complaint. "Obfuscation" is a common description, suggesting that lawyers deliberately choose language that masks their true intentions. But though the late H.W. Fowler, in his magisterial Modern English Usage, ${ }^{105}$ speaks disparagingly of what he calls "officalese" 106 and "sociologese"107, he has some very kind - and indeed apt - 
things to say about legalese. After quoting a lengthy example of legalese, he writes,

This is certainly not pretty or luminous writing. But it is not officialese, nor is it circumlocution. It is legalese, and the reason why it is difficult to grasp is not that it wanders verbosely round the point but that it goes straight there with a baffling economy of words. It has the compactness of a mathematical formula. Legalese cannot be judged by literary standards. In it everything must be subordinated to one paramount purpose: that of ensuring that if words have to be interpreted by a Court[,] they will be given the meaning the draftsman intended. ${ }^{108}$

To illustrate Fowler's point about the peculiar attributes of good legalese, I present the case of the Uniform Simultaneous Death Act. ${ }^{109}$ (Inasmuch as different States have adopted their own versions of the Uniform Act, I shall use the Illinois version.) Suppose Smith executes a will that provides in part, "I devise Blackacre to $\underline{\mathrm{A}}$; but if $\underline{\mathrm{A}}$ should predecease me, then to $\underline{\mathrm{B}}$." Suppose further that Smith and $\underline{\mathrm{A}}$ die in the same automobile accident, and we cannot determine whether

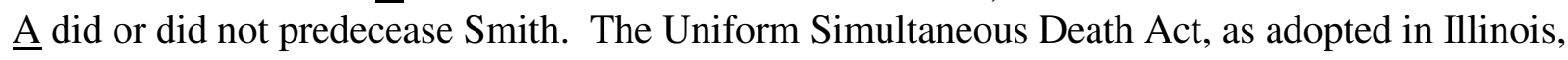
provides the following default rule (in the absence of a testamentary provision dealing with this survivorship problem):

If the title to property or its devolution depends upon priority of death and there is no sufficient evidence that the persons have died otherwise than simultaneously [, . . . t] he property of each person shall be disposed of as if he had survived. 110

To critics of legalese, the italicized words look like the perfect example of legalistic obfuscation. One can almost hear the cry, "Why not simply say 'if the persons died simultaneously'?" In fact, however, the statutory language does exactly what it is supposed to do. If the language were changed as proposed by these hypothetical critics, the statutory solution would be available only if one could prove that the persons actually did die simultaneously. And how often would one be able to prove that? The problem at which the statute is aimed is a problem that arises not only when the persons actually die simultaneously but also whenever one cannot prove that the deaths were not simultaneous: that is, when one cannot determine who died first. The existing statutory language does reach this broader range of circumstances. 111

\section{b. [T]ruth suppressed: Litotes and Euphemisms}

When the speaker in Sonnet 138 says "my days are past the best" instead of "I am old," we do not squirm with discomfort at this evasion; we chuckle with appreciative recognition. But when a government official declares "I was less than candid" instead of "I lied," we sense that the time for squirming has come.

Euphemisms may have begun as a way to ward off evil spirits. The Furies (in Greek, Erinnyes ( $E \rho(v \cup \in S)$ ) were three sister-goddesses of vengeance "who punished by their secret stings the crimes of those who escaped or defied public justice." 112 So terrifying were they to contemplate 113 - or even to mention by name - that the Greeks customarily referred to them as the "Kindly Ones" (in Greek, Eumenides (Evje $<\llcorner\delta \in S$ )), lest referring to them directly have the effect of summoning them. 114 Even today, we sometimes consciously avoid the straightforward naming of things that frighten us: e.g., referring to cancer as "the Big C."115 And estate planners frequently hear clients refer obliquely to their eventual deaths by means of the phrase "if something should happen to me," as if the event for which attorney and client are planning is 
only a possibility, merely one of any number of transitory interruptions that might or might not occur in the future. This habit of mind in clients requires a good deal of sensitivity on the part of an estate planning attorney. On the one hand, she wants to avoid sending her clients into a morbid panic through excessive bluntness, since few of us (including, presumably, the attorney) can contemplate our own deaths dispassionately. On the other hand, she must be sure that her clients understand that they are planning for something that will occur, not for something that simply may occur. Besides, clients may actually welcome an opportunity to talk about their fears of death, including fears of leaving their minor children abandoned and uncared-for, so the attorney should not signal to her clients any reluctance to engage in such a discussion. 116

Euphemisms like "the Kindly Ones" or "the Big C" are relatively harmless. They make life pleasanter, and no one is fooled. But some euphemisms do a great deal of harm; they camouflage reprehensible conduct and shield it from penalty. Few euphemisms are as atrocious as "the Final Solution to the Jewish Question" ("die Endlösung der Judenfrage") to refer to the Nazis' systematic extermination of European Jews. One would have supposed that the horror of those events and the retrospective ghastliness of the perpetrators' coded language would have so sickened us of political euphemisms that we would never again employ them. Yet today we refer to the unplanned wartime killing of civilians and destruction of their homes as "collateral damage," as if such occasions were not tragedies but simply normal wear and tear. We apply the phrase "extraordinary rendition" to the secret transfer of captured suspects to the jurisdiction of a foreign country expected to torture them. ${ }^{117}$ And, albeit on a less heinous level, the executives of pharmaceutical manufacturers apply the innocuous term "publication planning" to their practice of planting in medical journals ghostwritten articles that are ostensibly disinterested but in fact calculated to promote the manufacturers' products. 118 Not only does this kind of linguistic disguise impede the enforcement of laws and norms, it also facilitates their violation by shielding perpetrators from a sense of their own culpability, and it brutalizes the rest of us by shielding us from a sense of our own complicity.

The euphemisms discussed so far are associated more with the political Right than with the political Left. But the Left has embraced another category of euphemisms, which has come to be known as Political Correctness. I suppose the impulse to call persons confined to a wheelchair " mobility-impaired" or "differently-abled" rather than "handicapped" or "crippled" seems superficially like the impulse to call aerial bombardment "air support", but in fact very different strategies are at work. The impulse behind the latter is camouflage and concealment. The impulse behind the politically correct euphemisms, on the other hand, is community-building: an anti-hegemonic reluctance to categorize any status as substandard and a communitarian desire to remove the implicit label of "other" from as many people as possible. Unfortunately, these politically correct euphemisms are sometimes brandished with such belligerent self-righteousness, and they are often so clumsy and ill-fitting, that they bring discredit upon impulses that ought to be commendable.

For example, one rarely hears any more the term "slum" or "ghetto" applied to an economically and socially blighted urban American neighborhood; we hear "inner city", even though many expensive white urban neighborhoods are geographically situated far more centrally than some poor Latino or Black neighborhoods. Similarly, while the old phrase "illegal alien" calls forth all sorts of unnecessarily disagreeable associations (felons from Mars!), the politically correct term " undocumented worker", in addition to sounding clinical and pompous, is both under- and over-inclusive. It is under-inclusive in that some noncitizens who entered this country without complying with our immigration laws have no intention of entering the labor force; that is, they are not "workers," even though they fall into the group to which the term "undocumented worker " is regularly applied. And the term is over-inclusive in that many native-born citizens who are 
undeniably working lack documents like a passport, an available birth certificate, or even a Social Security number. ${ }^{119}$

Sometimes the imprecision of politically correct neologisms can be comical. Consider this scene from a play in which a white Dean of Students (who had previously been an administrator at a historically Black college called Lancaster College) has a conversation with the white President of a mostly-white college that has recently hired the Dean: a conversation in which the President struggles absurdly to avoid uttering the blunt but obviously applicable word "Black."

Kenney [the president]. (speaking about the dean to a third party) She's our liaison to the minority students.

Sarah [the dean of students]. [W] hat was that about my being a liaison to the minority students[?]

Kenney. Oh well, because of the Lancaster thing.

Sarah. Pardon?

Kenney. Well, you know we consciously set out to diversify, and we really wanted your experience, coming from Lancaster. Serving a more [pause] diverse student population. Sarah. It wasn't really diverse.

Kenney. Then a minority population.

Sarah. I was in the minority.

Kenney. Then an African-American population. Is that what you wanted me to say? ${ }^{120}$

However well-intentioned President Kenney may have been, her reluctance to utter the word " Black" or "African-American" betrays a patronizing and even stigmatizing anxiety, as if she thought Blackness too mortifying a quality to be mentioned directly.

And sometimes politically correct neologisms can have a harmful effect on policy. Schoolchildren who have exceptional difficulty grasping the standard curriculum used to be described as "mentally retarded." Now, more often, we hear the phrase "special needs". ${ }^{121}$ It is true that schoolchildren of less than average intelligence require special attention from teachers and administrators if they are to achieve and flourish. But the same can - and should - be said of schoolchildren of exceptionally high intelligence, who, without special attention, are denied the opportunity of realizing their full intellectual potential:

[A]cademically gifted students ... need educational services not usually ... provided in regular classrooms. These students are not just learning machines, rapidly acquiring knowledge and skills (although they do that). Their reasoning and insight are like those of older students; they are capable of making distant connections and corralling multiple resources in their problem solving; most are passionately curious; many are highly creative when given permission to "think outside the box." At the same time, ... they are socially, emotionally, and academically vulnerable to chronically underchallenging educational settings. They are especially vulnerable in the everyday company of age peers from whom they experience pressure to conform, but among whom they find few to none with whom they can communicate their thoughts and insights. ... Their loss is a loss not only to them, but a loss of their future leadership of the very society that has been so blatantly unable to solve its social problems. 122

As long as "special needs" is used as code for "mentally or developmentally disabled", rather 
than as shorthand for "requiring exceptional educational services", Americans will continue to overlook the problems that exceptionally gifted students face and will continue to lose much of the benefit that those students might confer on our society.

All right, then. Politically correct euphemisms are asinine. And clumsy and pompous and priggish and self-congratulatory. But would it really be a better world if instead we felt free to apply words like "slum" or "retarded"? To me, it's a question of courtesy. Good manners may seem today to be an insubstantial doctrine to preach, but it is one that I commend to my readers' attention. In his poem "A Prayer for My Daughter", William Butler Yeats chose "courtesy" as the quality in which he'd "have her chiefly learned."123

\section{c. Telling [L]ies to Gain Sexual Access}

The speaker and his mistress in Sonnet 138 tell each other lies in order to maintain untroubled sexual relations. Their lies are mutual, of course, and neither of them is in fact deceived, but this pattern of behavior has broader implications. Suppose only one party is lying and the other party is deceived. Obtaining property by false pretenses is an actionable tort ${ }^{124}$ (as well as a crime 125 ), but what about obtaining sexual acquiescence by false pretenses?

Acquiring property from another is neither criminal nor actionable if the property was obtained with the transferor's consent. We treat acquisition by fraud as both criminal and actionable in part because the transferee's misconduct, in inducing the victim to relinquish something of value, undermines any claim by the transferee that the transferor consented to part with it. As a matter of abstract legal doctrine, therefore, "gaining sexual cooperation by fraud is as culpable as other forms of deceptive appropriation that are already (and uncontroversially) unlawful."126 As a practical matter, however, "a man may [legally] do things to get a woman's agreement to sex that would be illegal were he to take her money in the same way." 127 This gap between doctrine and practice may reflect a suspicion that sexual access is not "something of value": that in an age when a lack of virginity hardly impairs a woman's marital prospects 128 and when in any event an unmarried woman can thrive financially, acquiescing in sex because of fraudulent misrepresentations does not produce a compensable harm ${ }^{129}$ but rather is "merely humiliating." 130

Of course, to argue that sexual fraud is noncompensable because its results are "merely humiliating" is an argument that proves too much, since damages for the tort of intentional infliction of mental distress have in fact been awarded based on conduct that "merely" produced humiliation. 131 But in those cases where damages were in fact awarded, the defendant's conduct was found to be outrageous in some way. ${ }^{132}$ Mental distress induced by non-outrageous conduct generally has been found not to be actionable. ${ }^{133}$ Our instinctive uneasiness with awarding damages for seduction by fraud may reflect a belief that lying to get sex is not outrageous behavior but actually commonplace behavior: "[E]verything in romance is lying and delusion[,] and . . . judgment goes out the window in sexual matters." 134 By this formulation, someone who is provisionally available for sex expects to be lied to or, at least, willingly suspends her disbelief; 135 and therefore the seducer acts reasonably in expecting no reliance on his lies by the seduced. Except in the most extreme cases "no clear social consensus [exists] about the circumstances in which misrepresentation in matters of sexual intimacy is improper." 136 
Professor Larson's article on this subject, which I have quoted earlier, is titled in part "A Feminist Rethinking of Seduction." 137 The model she uses to present her argument presupposes that it is the male who is the deceiver and the female who is the deceived. Popular culture certainly confirms such a model: the woman naive and credulous; the man nimble and calculating. Indeed, popular culture goes further and commends to women the "virtues" of naivté and ignorance as a way of demonstrating a becoming femininity. ${ }^{138}$ Ironically, the speaker in Sonnet 138 inverts this common prejudice; it is he - not the woman - who pretends to credulousness as a way of maintaining his sexual desirability to the other.

\section{d. On both sides: Paying for Sexual Access}

The speaker in this sonnet uses the language of commerce to describe a sexual relationship. Yet we feel instinctively that sexual access is not a fit subject for contractual arrangements. Is this instinct sound or merely sentimental?

Prostitution is the classic example of the intersection between sex and commerce. ${ }^{139}$ Despite the example set by the male speaker in Sonnet 138, the question whether to legalize prostitution, like the question whether to treat seduction as an actionable tort, is almost invariably considered in a gendered context with women, not men, acting as the sellers of sexual access. Indeed, so deeply ingrained is the assumption that prostitutes are female that some commentators who mention male prostitution betray their surprise and discomfiture by using the phrase "male prostitution" even when the context makes the prostitute's male gender clear, as if to suggest that male prostitution is so aberrant that its existence cannot be merely alluded to but must rather be accentuated. 140 Nonetheless, because gender roles underlie so many of the arguments historically presented both on behalf of and in opposition to prostitution, ${ }^{141}$ I shall confine my discussion to the case of female prostitutes serving male clients.

The objections to prostitution begin with the assertion that exchanging sex for money is immoral: an assertion that provokes two responses. First, many things are agreed to be immoral - lying and adultery, for instance - yet are also agreed not to be fit subjects for the criminal law, except in the most unusual cases (such as lying under oath in court). Second, in many contexts, the exchange of sex for money is not considered immoral. In a medical context, the provision of sexual services by a sexual surrogate, for money, seems not to be the sort of act contemplated by laws prohibiting prostitution. And in a marital context, the interspousal exchange of sex for money is not illegal. ${ }^{142}$ Thus, the moral foundation of anti-prostitution laws is more likely to be a sense that the exchange of sex for money (outside of the privileged marital context) degrades society and those who engage in it, just as laws against cruelty to animals are justified as a means to prevent the brutalization of the perpetrators rather than as a means to make life pleasanter for animals. 143 Indeed, West Virginia, for one, places its "cruelty to animals" statute in the same article (Article 8 of Chapter 61) as its prostitution statute; the article is titled "Crimes against Chastity, Morality and Decency."144

What is the nature of the degradation thought to be associated with prostitution: the degradation that justifies criminalizing it? No doubt, physical intimidation and violence play an enormous role in the lives of many prostitutes, ${ }^{145}$ but the more logical response to that situation is to enforce more rigorously the existing criminal laws prohibiting physical intimidation and violence; 146 and the victimized prostitute is more likely to aid in such enforcement (or to seek its benefits) if she can do so as someone accounted a law-abiding citizen. ${ }^{147}$ Another locus of the degradation traced to prostitution is the prostitute's mental health, which necessarily suffers 
when she must regularly detach her mind from her body in order to perform sexual acts without personal affect. ${ }^{148}$ But we have seen that lawyers, too, must sometimes detach themselves from their own feelings in order to give effective representation to a repugnant client. ${ }^{149}$ The exceptionally high suicide rate and incidence of depression among lawyers suggest that they pay a high psychic price for following their particular vocation, ${ }^{150}$ yet I am aware of no seriously-intended calls for the abolition or criminalization of their profession.

Other critics of prostitution argue that it institutionalizes the subordination of women as a class and, indeed, constitutes part of a "continuum of violence" against women: from sexual harassment to domestic abuse to rape. ${ }^{151}$ Such an analysis of prostitution requires a rethinking of the concept of "consent." In Sonnet 138, both the speaker and the mistress enter into the bargain as equals and with their eyes open. Proponents of the decriminalization of prostitution likewise view prostitution as a transaction freely entered into, and it is certainly true that " [p]rostitution is one of [the few] unskilled jobs where women on average earn more than men." 152 But this last group of critics of prostitution responds by arguing that the characterization " freely entered into" ignores the realities of women's experience: their lack of choice and their economic and physical vulnerability. ${ }^{153}$ By this view, prostitutes are their customers' victims, not their commercial associates - one critic uses the provocative description "buying the right to rape" 154 - and accordingly such critics argue for the discontinuation of criminal penalties against the prostitute but continued criminal penalties against the customer. ${ }^{155}$

\section{e. [T]hough I know she lies: Summoning a Liar as a Witness}

The speaker know [s] [line 2] his mistress is lying about her constancy, and she knows [line 6] he is older than he pretends to be, yet each deliberately acts as if he trusted the other's truthfulness. The prospect of winking at obvious dishonesty raises particularly intense ethical problems for the trial lawyer. Suppose a criminal defendant wishes to testify in his own defense, and his lawyer suspects that the defendant will perjure himself if called. May the lawyer, consistently with the rules of professional conduct, allow her client to testify? The American Bar Association Model Rules of Professional Conduct state:

If a lawyer, the lawyer's client, or a witness called by the lawyer, has offered material evidence and the lawyer comes to know of its falsity, the lawyer shall take reasonable remedial measures, including, if necessary, disclosure to the tribunal. A lawyer may refuse to offer evidence, other than the testimony of a defendant in a criminal matter, that the lawyer reasonably believes is false. 156

This rule distinguishes between a lawyer's actual knowledge of testimonial falsity (to which the speaker and his mistress admit) and a mere reasonable belief that the testimony is false. If the lawyer has actual knowledge that a witness's statement is false, the lawyer must take steps to protect the court from the deception. But if she merely has a reasonable belief that the witness's statement is false, she is not required so to inform the court. This distinction relieves the lawyer of the burden of being a trier-of-fact; it gives the lawyer leeway to present evidence helpful to her client - however suspect such evidence might be - and leave it to the jury to decide whether to believe it. If instead the rule barred a lawyer from introducing evidence of whose veracity she was suspicious, clients would be well-advised to choose the most credulous lawyer they could find, so as to give her the maximum flexibility in introducing evidence on their behalf; and a legal system that puts a premium on gullibility is not the sort of system I would trust. 
The first sentence of the quoted rule states that the lawyer must refuse to introduce evidence that she knows is false; but the language of the rule as a whole indicates that the lawyer need not refuse to introduce evidence merely because she has a reasonable belief in its falsity. But may the lawyer (consistently with the duty of providing diligent representation ${ }^{157}$ ) refuse to introduce evidence in whose falsity she has a reasonable belief? After all, if the lawyer does introduce dubious evidence, the jury is not unlikely to share her doubts, in which case the lawyer is not helping her client and may indeed be injuring her own professional reputation for probity and reliability. The second sentence of the quoted rule - presumably for the reasons I have just stated - explicitly authorizes the lawyer to refuse to introduce the doubtful evidence, unless the lawyer is defending the client in a criminal matter and the doubtful evidence in question is the defendant's own testimony. In that situation, the lawyer may refuse to allow the client to make testimonial statements only if the lawyer knows that the statements are false; if she merely has a reasonable suspicion that the statements are false, she must allow the client to make them. This special rule for testimony by criminal defendants seems to reflect the view that a defendant's interest in preserving his own liberty (as opposed to a civil litigant's interest in preserving his own property) outweighs the lawyer's interest in preserving her reputation for candor.

\section{Sonnet 121}

This complex, almost combative sonnet belongs to the Young Man sequence, but here the speaker's usual role has been reversed. Instead of reproaching the young man for the young man' $\mathrm{s}$ wantonness, 158 the speaker in this sonnet is responding to charges of wantonness brought against himself by the world at large. The response explores a favorite theme in the Sonnets: the disjunction between appearance and reality.

1'Tis better to be vile than vile esteemed,

2 When not to be receives reproach of being,

3 And the just pleasure lost, which is so deemed

4Not by our feeling but by others' seeing.

5 For why should others' false adulterate eyes

6 Give salutation to my sportive blood?

7Or on my frailties why are frailer spies,

8 Which in their wills count bad what I think good?

$9 \mathrm{No}$, I am that I am, and they that level

10At my abuses reckon up their own;

11I may be straight though they themselves be bevel;

12By their rank thoughts my deeds must not be shown

13 Unless this general evil they maintain:

14 All men are bad and in their badness reign.

The sonnet begins with an astonishing declaration of principle: that it is better to be vile than to be thought vile by others. Yet the line's accents suggest that this paraphrase is inadequate, or at least incomplete. My paraphrase accents the word be, but the speaker's iambic pentameter accents the word vile. So after we read the first five words, with the accent on vile, we expect the line as a whole to take this form: 'Tis better to be vile than to be $X$, where $X$ describes some other human quality. And since few human qualities are worse than vileness, we expect $X$ to be very bad indeed. Yet $X$ turns out to be merely "being thought vile by others." Why is that so bad? The speaker goes on to explain.

Lines 2-4 qualify what seemed in Line 1 to be an unqualified statement. (Indeed, if I were punctuating this sonnet afresh, I would allow no punctuation at the end of Line 1.) While Line 1 
draws a distinction between appearance (vile esteemed) and reality (be vile), Line 2 draws what should be a sharper distinction, between two contradictory realities: being vile in fact (being) and not being vile in fact (not to be). Yet the speaker posits in Line 2 a state of affairs in which these contradictory realities give rise to an identical response from others, reproach - that is, a state of affairs in which the world at large unjustly accuses a virtuous person of vileness - and the conjunction When that begins Line 2 signals the speaker's belief that it is this injustice that makes "being thought vile" worse than "being vile in fact." Undeserved accusations of vileness, according to Line 3, deprive the virtuous person of the rewards (pleasure) of being virtuous: an inner sense of rectitude and the joy of basking in the good opinion of others. Traditional morality tells us that virtue is its own reward and that the upright person should not look for any external praise or admiration. Jesus warned his listeners against trumpeting their own good deeds and praying noisily and conspicuously as a way of attracting the admiration of other people. 159 Yet the speaker, contrary to these authorities, asserts that it is legitimate (just) to expect these rewards and to feel aggrieved when denied them, particularly when (according to Line 4) one is deprived of these rewards not because one considers oneself unworthy (Not by our feeling) but only because others think one is unworthy (but by others'seeing).

To understand the special sting of being unjustly thought vile, we need to revisit the word pleasure in Line 3. Vileness has its pleasures (sexual satiety, for instance) no less than virtue. Why, asks the speaker, should a person deny himself the pleasures of vileness [w] hen [Line 2] he must endure the same public reprobation that the truly vile must endure? As long as he must live with a reputation for vileness anyway, he may as well experience the pleasures of vileness.

This opening polemic leads us to expect a comic or cynical resolution, ${ }^{160}$ but, as the speaker shifts from the abstract to the personal in the second quatrain, we discover that he is not amused but indignant. The speaker objects to being judged vile by other people's false adulterate eyes [Line 5]. Adulterate here is an adjective, ostensibly meaning polluted or defective and therefore unable to function correctly, but the word might also mean adulterous 161 and therefore disqualified from criticizing the sexual conduct of others. The noun being modified by adulterate is, significantly, eyes, for this sonnet treats the eye as the organ of moral judgment: not the mind or the heart, but the eye. ${ }^{162}$ Indeed, in keeping with the theme of appearance and reality, the eye plays this critical role throughout the sonnet: others 'seeing instead of "others' judging" in Line 4; spies instead of "judges" in Line 7; shown instead of "construed" in Line 12. And the speaker's synonyms for "virtuous" and "dissolute" in Line 11 - straight and bevel respectively - convey their meanings by visual associations.

Even the reader's eye participates in the action of this sonnet. VILE, the driving word in the sonnet's first line, and EVIL, the driving word in the couplet's first line, are more than just synonyms. They are anagrams. 163 Shakespeare played with anagrams in other works as well, notably in Twelfth Night, ${ }^{164}$ but this anagram pair in the sonnet belongs to a rare, though not unique, group: a quartet of 4-letter anagrams. VILE, EVIL, VEIL, LIVE. 165 Consequently, the absence of VEIL and LIVE in this sonnet is worth noting. 166

The first five lines of the sonnet deal in abstractions. Even the first-person pronoun our in Line 4 , being a plural, does not point to anyone in particular. But in Line 6, with the pronoun my, we finally learn that the speaker's anger at the world's false judgments is brought on not by its false judgments of people in general but rather by its false judgments of the speaker himself. From Line 6 onward, the speaker shifts continually between I/my and they/their in his quest to identify the fitter judge. Note the sequence of personal pronouns:

My 


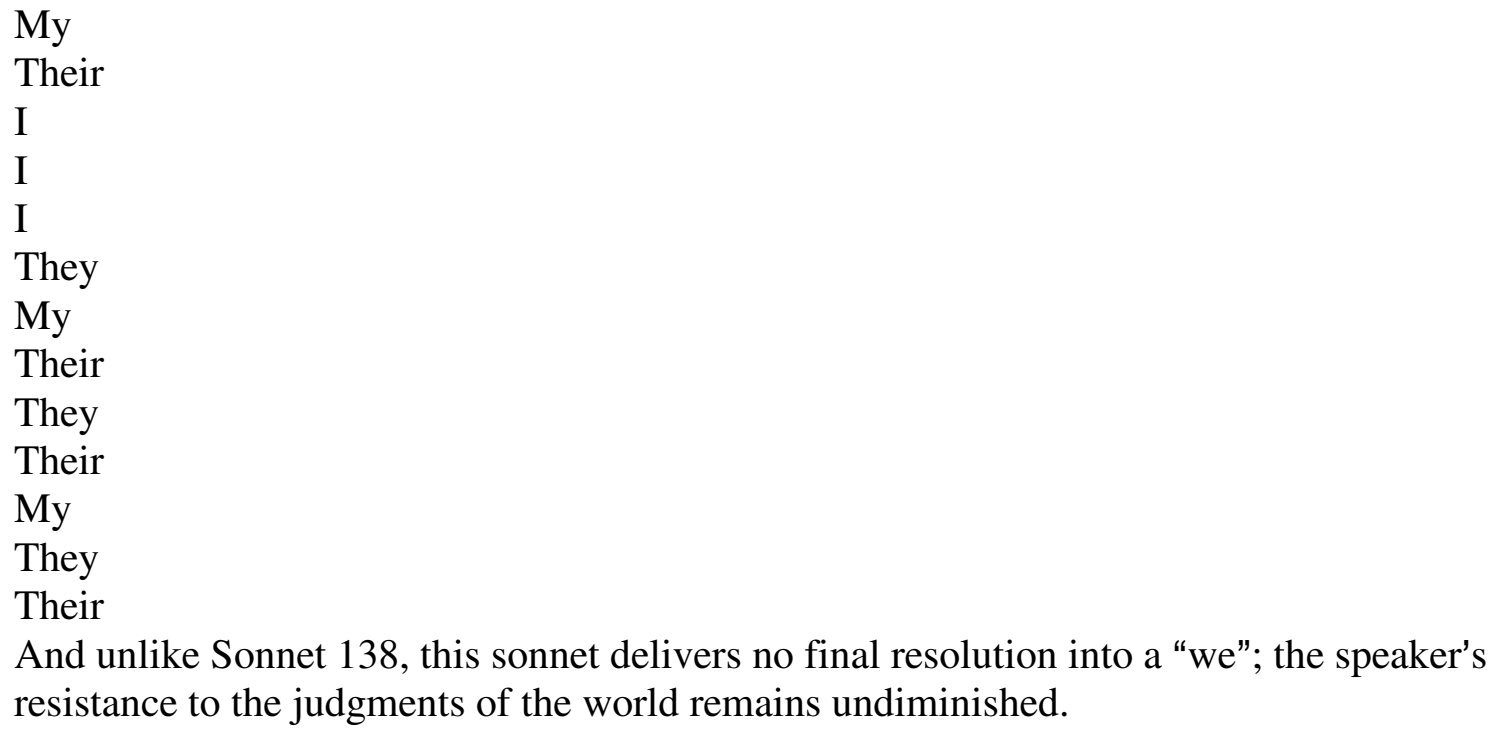

The world's judgment of the speaker consists in its giv[ing] salutation to [his] sportive blood. Sportive blood clearly means lascivious behavior. ${ }^{167}$ But what does the speaker have in mind in the earlier part of Line 6 when he complains of his traducers' eyes giv[ing] salutation to his lasciviousness? That is, when these traducers give salutation to his lasciviousness, what exactly are they doing? Again, the image is visual; these traducers are presuming to observe and recognize in the speaker these qualities of lasciviousness, perhaps giving him a wink of familiarity that offends the speaker deeply. Their familiarity outrages him because they are, he thinks, in no position to judge him; they are even frailer [Line 7] than he 168 and therefore even less fit to distinguish bad from good [Line 8]. How dare they impute to him the very badness of which they themselves are guilty? We like to think that we rely on our own moral judgment in distinguishing bad from good, but the speaker confronts a world peopled by self-appointed arbiters of morality who make these distinctions as acts of pure will[] [Line 8], based on their own compromised perception. And inasmuch as the noun will, in Elizabethan and Jacobean times, also meant "carnal desire", 169 the speaker suggests here that his traducers are making their determinations of badness and goodness by projecting their own licentiousness onto others.

"Judge not, that ye be not judged," Jesus warned his listeners on the Mount, 170 and he enjoined those who assembled for the execution of the woman taken in adultery, "Let him that is among you without sin cast the first stone at her." 171 These two famous passages are often taken (wrongly) to mean that no one is fit to judge anyone else: that no human being is competent to determine that another's conduct is wrongful. ${ }^{172}$ That cannot be correct. We do not require judges to be wholly without sin in order to sit on the bench or police officers to be wholly without sin in order to make an arrest. If no one is fit to condemn any malfeasance or crime, then nothing is forbidden and we return to a state of nature, where might makes right. It is true that we act at our peril when we condemn others, but the peril Jesus warned against is hypocrisy, not error. And his most vivid image of the hypocrite, like many of the images in Sonnet 121, emphasizes the eye.

And why seest thou the mote, that is in the brother's eye, and perceivest not the beam that is in thine own eye? Or how sayest thou to thy brother, suffer me to cast out the mote out of thine eye, and behold a beam is in thine own eye? Hypocrite, first cast out the beam out of thine own eye, and then shalt thou see clearly to cast out the mote out of thy brother's eye. ${ }^{173}$ 
What makes our moral condemnation of others wrongful, says the Bible, is not the harshness or inaccuracy of our judgments but rather their foundation, if that foundation involves self-righteously or hypocritically projecting our own frailties [Line 7] onto others.

The speaker's claim in the sonnet seems less modest, however. He goes beyond saying to his accusers, "You're just as bad as I am." He says, "You're worse (frailer)." And he does question the accuracy of their judgments: [they] count bad what I think good. So whose moral judgment is more accurate: the speaker's or the world's? The speaker does not stoop to answer the two questions he poses in the sonnet; instead he defiantly repudiates them and makes a presumptuous claim of freedom from others' judgments and of sovereignty over his own conduct: I am that I am [Line 9]. What makes the claim presumptuous - indeed, almost shocking - is its deliberate appropriation of God's words to Moses. When Moses receives God's instructions on Mount Horeb, Moses fears that the Israelites will demand God's name when he tells them that God has sent him, and he asks God how he should answer such a demand. God replies that Moses should answer "I am that I am." 174 It is as if God had declared, "Don't explain me or defend me. Don't offer them my name, lest they call on me familiarly ([g]ive salutation to). Just tell them I am that I am. That is all they need to know."

The speaker's assumption of Godhead in line 9 can be characterized in many ways - arrogant, ugly - but at least it is not hypocritical. No furtive sinner, he. Still, his declaration of self-dominion is so excessive that one cannot help suspecting that he is speaking more in anger than in reflection. Indeed, the speaker grows angrier with each quatrain. In the first, he speaks in generalizations about the injustice of being inaccurately judged. In the second, he reveals his personal anger at being judged by his moral inferiors. And in the third, he expresses his outrage at being judged by anyone at all. I may be straight, he says in Line 11, rather than "I am straight. " That is, "I may be upright or I may not be upright, but I am that I am and you shall not judge me. By presuming to judge me for my alleged wrongs [abuses], you are merely projecting onto me your own wrongs and thereby incriminating yourselves [reckon[ing] up [your] own]."

The word level, which ends the first line of this third quatrain, startles the attentive reader with its extra syllable. Along with bevel, it forms a feminine rhyme, 175 the only such rhyme in this sonnet, 176 and the very singularity of this rhyme device suggests that the speaker's choice of these words has special importance for him. 177 The speaker uses level as a verb meaning "take aim" 178 but the word can have other meanings as well, and in keeping with this poem's visual emphases, these other meanings call forth visual images. It can be an adjective meaning "flat." It can be a verb meaning "to flatten" or "to make uniform," as if the speaker resents the traducers for attempting to bring him down to their "level" (here it is a noun).

The speaker completes the feminine rhyme with the word bevel in Line 11: a word that appears nowhere else in Shakespeare. While we use the word today as a noun or a verb, the speaker uses it as an adjective, meaning "slanting" or "at an angle other than 90 degrees," and he uses it to contrast with the adjective straight in the same line. ${ }^{179}$ Again, the speaker uses these visual adjectives to denote moral conditions, just as we would today in casual speech: "I may be upright though they themselves be crooked."180

The speaker ends the third quatrain with a simple restatement of his objection to being judged by evil-minded others. Like Line 1, which appears to be an absolute statement but is instead qualified immediately by the succeeding line beginning with the conjunction When, Line 12 also appears to be an absolute statement but is qualified immediately by the succeeding couplet 
beginning with the conjunction Unless. ${ }^{181}$ The speaker says that he will withdraw his seemingly unqualified objection to being judged by these rank-thinking traducers if they in return are willing to subscribe to this general assessment: All men are bad. ${ }^{182}$ The speaker will suffer these traducers to judge him vile provided they are willing to admit that everyone is vile. And why should such an admission make these traducers' disapprobation of the speaker less objectionable to him? Because if these traducers admit that they, too, are vile, then they cannot be guilty of hypocrisy when they accuse him of vileness. 183 Jesus did not warn against judging per se but only against judging self-righteously or hypocritically; consequently, by admitting their own vileness these traducers have purged themselves of their disqualification from judging. 184

But there is more to Line 14 than All men are bad. The whole line is All men are bad and in their badness reign, and the antecedent of the pronoun their is not altogether clear. The antecedent might be (1) [a]ll men, or it might be (2) the traducers (that is, the same persons to whom the pronoun they in Line 13 refers). Under the first interpretation, the speaker is willing to tolerate the traducers' judgments if the traducers admit to two things: that all men are bad, and that badness is the power that drives human society. Under the second interpretation, the speaker is willing to tolerate the traducers' judgments if the traducers $d o$ two things: they must admit that all men are bad, and they must openly rejoice in their own badness (again, no furtive sinning allowed). This second interpretation organizes the text this way:

Unless this general evil they maintain: "All men are bad;" and unless they rule in their badness.

The Quarto's lack of any comma in Line 14 might incline the reader toward the first interpretation, but I have already warned against basing interpretations on the Quarto's punctuation; 185 and in fact a number of editors have inserted a comma between bad and and. I find the second interpretation more satisfying and compelling. Since the target of the speaker's anger is the traducers' hypocrisy, he is more likely to tolerate their judgments if they emphatically renounce hypocrisy by openly exulting in their own badness rather than merely shrugging it off with the impersonal, commonplace observation that everyone is bad.

\section{a. [S]portive Violence}

Today, the word "sports" (or, in British usage, "sport") refers to athletic competition, particularly competition between teams. But Shakespeare used "sport" and "sportive" as a reference to recreational sex. 186 In King Lear, for instance, the Earl of Gloucester, reminiscing about the conception of his illegitimate son, remarks that he cannot altogether regret having sired him inasmuch as the mother was pretty and the sex was hot: "[Y]et was his mother fair; there was good sport at his making." 187 I would argue that this apparent change in meaning is not a change at all; the connection between athletic triumphalism and violent or sexual conquest remains strong and pervasive. As recently as August of 2008, when three high school students were charged with homicide or aggravated assault in connection with the beating death of a Mexican man living in their small Pennsylvania town, the New York newspaper reporting the events saw fit to mention that all three were members of the high school football team. ${ }^{188}$ And a study of sexual assaults at major American universities during the 1990s found that while male student athletes make up 3.3 percent of the college population, they committed 19 percent of the sexual assaults: almost six times the general rate. 189 
Some have hypothesized that the high rate of sexual assaults among college athletes stems from their sense of privilege engendered by the campuswide adulation of their athletic accomplishments. 190 But the rich sons of rich alumni no doubt arrive at college with a sense of privilege, too, yet I am unaware of any statistical demonstration of their greater likelihood of committing sexual assaults. To me, a more likely explanation is to be found in the misogyny and homophobia in which our athletes are chiefly learned. ${ }^{191}$

[F]ootball coaches are well known for berating their players with insults: "Ladies," " faggots," "pansies." 192

One coach hung a bra in a player's locker to signify that player wasn't tough enough. In order to inflame aggression or compliance, coaches called players "pussies" or " limp wrists" and told them "go home and play with your sisters" or "start wearing silk panties."193

Male coaches send strong messages about women and about the need for men to avoid being like women when they compare a poor performance by a male athlete to that of a girl (for example, throwing like a girl). 194

Our culture conditions male athletes to think of athletic skill as a uniquely masculine quality. A high school basketball coach in Maine directed his players at halftime to put their hands down their pants to "check their manhood" before returning to the game, telling them that the game " was about who had the biggest [male genitalia] in town." 195 One hesitates to disagree with a professional, but I should have thought that small genitalia would be more conducive to fast maneuvering on the court. In any event, when the coach was criticized for having made the remark, he responded by saying, "We won," 196 implying that he perceived a causal link between phallic pride and athletic success; moreover, he claimed that such remarks by a coach are " normal locker room banter from Fort Kent, Maine, to San Diego, California." 197

These athletic coaches are relying on shame as a motivational tool, and the propellant of that shame is misogyny. "In the hierarchical and rigorously competitive society of other boys, one categorical imperative outranks all the others: don't be a girl."198 And these coaches, by hurling "faggot" in their teams' faces along with "pussy", recognize that homophobia can be relied upon to serve a similar function.

The central outrage of [male-male] sex is that a man is reduced to the status of a woman, which is understood to be degrading. ... [H] omosexuality is threatening because it calls into question the distinctive and superior status of being male. 199

The link between locker-room attitudes and military attitudes is too evident to require much substantiation. Historian Paul Fussell in Wartime, his analysis of the American and British home fronts during the Second World War, observed that male soldiers in combat "will attack only if young, athletic, credulous, and sustained by some equivalent of the buddy system - that is, fear of shame."200 And a civilian commission charged with examining a recent spate of sexual assaults at the United States Air Force Academy concluded that sexual assaults by male cadets on female cadets were "frequent and unpunished." 201

The world can be a dangerous and violent place. I am not entirely unsympathetic to the view that we cannot afford to let our soldiers be any less aggressive and brutal than our opponents' 
soldiers, ${ }^{202}$ but we need to acknowledge the nonpecuniary costs of cultivating that degree of ferocity.

\section{b. Unjustly Enjoying the just pleasure: Why Is Hypocrisy So Harmful?}

According to the Gospels, Jesus spoke of a number of sins but none more frequently or more censoriously than the sin of hypocrisy. ${ }^{203}$ Abraham Lincoln, in a famous letter to his friend Joshua Speed, likewise spoke of hypocrisy as a peculiarly detestable offense.

Our progress in degeneracy appears to me to be pretty rapid. As a nation, we began by declaring that "all men are created equal." We now practically read it "all men are created equal, except negroes." When the Know-Nothings [a nativist American political party of the 1850s] get control, it will read "all men are created equal, except negroes, and foreigners and catholics." When it comes to this[,] I should prefer emigrating to some country where they made no pretense of loving liberty - to Russia, for instance, where despotism can be taken pure, and without the base alloy of hypocrisy. 204

Hypocrisy is more than a mere failure to live up to one's expressed ideals; we are imperfect creatures, after all, and do not always practice what we preach. ${ }^{205}$ Hypocrisy involves "pretense ", to reiterate Lincoln's remark, and it goes beyond mere lying. The hypocrite professes beliefs that he does not really hold or flaunts a virtue that he ought to know he does not really possess. 206 If someone asks a drug addict, named $\underline{\mathrm{A}}$, "Are you a drug addict?" and $\underline{\mathrm{A}}$ answers "no," $\underline{\mathrm{A}}$ may be a liar, but he is not a hypocrite. But if $\underline{A}$ has made a public career out of demonizing drug addicts and calling for their harsh punishment, then $\underline{A}$ has moved beyond lying and attained true hypocrisy.

Recent events have showcased some rather notorious examples of hypocrisy. Rush Limbaugh, a popular conservative radio and television personality, famously included drug addicts among the targets of his vitriol and contempt. In a 1993 broadcast, he said

[S]end the people who want to do drugs to London and Zurich, and let's be rid of them. . . . I'm appalled at people who simply want to look at all this abhorrent behavior and say people are going to do drugs anyway [so] let's legalize it. It's a dumb idea. . . . 207

And in a 1995 broadcast,

Drug use destroys societies. Drug use, some might say, is destroying this country. And we have laws against selling drugs, pushing drugs, using drugs, importing drugs. And these laws are good because we know what happens to people in societies and neighborhoods which become consumed by them. And so if people are violating the law by doing drugs, they ought to be accused and they ought to be convicted and they ought to be sent up [the river to prison]. ${ }^{208}$

The American press later revealed, however, that Mr. Limbaugh had for years (including the years during which he made the quoted broadcasts) been addicted to prescription painkillers, consuming them in such high quantities as to suggest to Florida law enforcement officials that he obtained them illegally. 209 Oddly enough, after conceding on his broadcast that the news 
reports of his addiction were true and then flying off to rehab, he made a point of saying, on his return to broadcasting, "There is no hypocrisy in this." 210 I disagree, of course; hypocrisy is exactly what it was, given his long record of self-righteous excoriation of drug addicts. 211 And his very denial of hypocrisy demonstrates an understanding of how very bad hypocrisy is. Just as Lincoln, albeit for rhetorical purposes only, suggested that hypocrisy was worse than racism, 212 Limbaugh seemed to recognize implicitly, by denying his hypocrisy while admitting his drug abuse, that hypocrisy is worse than drug addiction.

But why is it worse? What is it about hypocrisy that makes it an especially grave transgression? I make two suggestions: one relating to unsuccessful hypocrisy and the other to successful hypocrisy. First, widespread hypocrisy leads us to suspect virtue. Once discovered (and it generally is), hypocrisy makes us cynical, and extreme cynicism (a willingness to believe anything bad) is closely akin to extreme gullibility (a willingness to believe anything good): a most undesirable quality for a member of a democratic polity to possess. Former congressman Mark Foley (R-Florida) had undertaken a worthy legislative project: the protection of children from sexual predation. 213 But now that there has come to light his practice of sending frequent sexual messages to underage male congressional pages whom he supervised, 214 future legislators who undertake to make child-protection a legislative priority can expect to be viewed with suspicion as persons who protest too much. Such unreflective cynicism weakens social incentives to be good, inasmuch as the reward of good actions then becomes suspicion rather than the just pleasure.

The second harm brought about by hypocrisy involves the successful hypocrite, one who is not found out. A person's success in leading a double life - say, publicly condemning homosexuality while surreptitiously enjoying frequent homosexual encounters - can induce him to regard himself as somehow exempt from the struggles and constraints affecting society at large. 215 I would not trust a legislator who exempted himself from his own enactments, inasmuch as he would have little understanding and no experience "of how [his] legislation actually bites." 216 I would not trust a judge who thought herself exempt from her own pronouncements; one cannot act justly toward others if one fancies oneself superior to those to whom the normal rules apply. The successful hypocrite can develop a contempt for the society he has successfully beguiled and for those of his fellow sinners who lack his skills in dissimulation or his powers of self-protection. For a vivid example of this contemptuous attitude, look to Roy Cohn as fictionally presented in Tony Kushner's play Angels in America. When Cohn's doctor informs him that Cohn has AIDS, Cohn objects ferociously to being labelled "homosexual."

[L]abels tell you ... one thing only: where does an individual so identified fit in the food chain, in the pecking order? Not ideology, or sexual taste, but something much simpler: clout. Not who I fuck or who fucks me, but who will pick up the phone when I call, who owes me favors. This is what a label refers to. Now to someone who does not understand this, homosexual is what I am because I have sex with men. But really this is wrong. Homosexuals are not men who sleep with other men. Homosexuals are men who in fifteen years of trying cannot get a pissant antidiscrimination bill through City Council. Homosexuals are men who know nobody and who nobody knows. Who have zero clout. Does this sound like me . .. ? . . This is not sophistry. And this is not hypocrisy. This is reality. I have sex with men. But unlike nearly every other man of whom this is true, I bring the guy I'm screwing to the White House and President Reagan smiles at us and 
shakes his hand. Because what I am is defined entirely by who I am. Roy Cohn is not a homosexual. Roy Cohn is a heterosexual man ... who fucks around with guys. 217

\section{c. [F]railer spies: Who Is Fit to Judge?}

When Lord Coke famously declared, "No man should be a judge of his own case," 218 he was stating a proposition we regard as self-evident. Of course no one should be permitted to try a case in which she is a plaintiff or a defendant. And, as a corollary, of course no one should be permitted, as an appellate judge, to hear an appeal from her own judgment. 219 But the speaker in Sonnet 121 espouses a more exacting standard of judicial disqualification: no one may sit in judgment unless she is more moral than the parties appearing before her. 220 More narrowly, no one may condemn conduct as wrongful if she herself is guilty of the same kind of wrong. To what extent have we adopted (or should we adopt) this standard of judicial conduct today?

Judicial decisions are not self-executing; a judge cannot personally compel compliance with her rulings. Without public confidence in her probity and impartiality and without the litigants' confidence that she used reason rather than idiosyncrasy to decide their case, she cannot discharge her duties effectively. Consequently, we hold judges to stricter standards of conduct than those applicable to ordinary citizens. 221 A judge may not, for instance, "hold membership in any organization that practices invidious discrimination on the basis of race, sex, religion[,] or national origin," 222 even though an ordinary private citizen may do so with impunity. And we require judges to render decisions arrived at "through proper judicial method and reasoning" and only after they have heard "all the parties in accordance with prescribed procedures." 223 They may not sit in judgment if they have committed themselves to a particular result before the evidence is presented. 224

Suppose a judge presiding at a trial for defamation has herself been an unsuccessful plaintiff in a defamation action. Should we expect her to be capable of hearing the parties' cases without predetermination and rendering a decision based solely on the facts and the law? For example, would the defendant have reason to fear that the judge would be biased toward the plaintiff because, as an unsuccessful plaintiff herself, she would be sympathetic to this plaintiff's pain and unwilling to see yet another victim denied compensation? Perhaps. But the plaintiff might have equal reason to fear bias toward the defendant because the judge might, in bitterness, prevent another plaintiff from succeeding where she herself had failed. The question is not which outcome is more likely or which party has more to fear from her bias. There is no way to tell. Rather, the question is, will she be deciding the case on the basis of particulars that were not part of the record. Counsel can argue against the other party's case, but how can he argue against a judge's private history?

Perhaps "private" is the key word here. The speaker in the Sonnet, raging against the hypocrisy of those who judge him, will nonetheless tolerate their judgments if they are willing to exult openly in their badness rather than nurturing their badness in secret. W.S. Gilbert, in his comic opera Trial by Jury, offers a witty example of just such judicial exultation. Before presiding over a damages action for breach of promise of marriage, the judge in the opera unblushingly admits to the assembled crowd that he himself has profited from just such a breach of promise. Weary of his poverty and obscurity as a young barrister, he calculatedly "fell in love with a rich attorney's elderly, ugly daughter." And after he became rich as the result of his prospective father-in-law's influence, well, let him tell it himself. 
At length I became as rich as the Gurneys [a then-prominent British banking family]

An incubus then I thought her,

So I threw over that rich attorney's

Elderly, ugly daughter.

The rich attorney my character high

Tried vainly to disparage -

And now, if you please, I'm ready to try

This Breach of Promise of Marriage! 225

Today, we would not take kindly to a judge who openly exulted in her questionable past, but we might respect a judge who disclosed to counsel her possible private interests and history, allowing counsel to determine whether their clients' interests would be better served by a different judge. 226

In today's political discourse about judges' qualifications, general ideology seems to have replaced particularized economic interest as the disqualifying characteristic par excellence, 227 and one often hears denunciations against the appointment of "activist judges." The term is invariably used pejoratively, but its meaning is exceptionally fluid, and its deployment seems to depend on whose ox is being gored. Often the term is used to excoriate judges who, say their conservative critics, use their judicial authority to flout the will of the voters.

Speaking to a bipartisan group of [supporters of a federal constitutional amendment banning same-sex marriage] at the White House on Monday afternoon, [President George W.] Bush repeatedly castigated what he called "activist judges" for thwarting the will of the people on same-sex marriage. "Marriage is the most fundamental institution of civilization, and it should not be redefined by activist judges." 228

"[An amendment to the Minnesota Constitution to ban same-sex marriage] is the only way to make sure activist judges don't circumvent the will of the people," argued Rep. Dan Severson, R-Sauk Rapids, the chief sponsor. . . 229

Yet Justice Scalia, who professes the most extreme solicitousness of popular opinion, at least as to sexual orientation, ${ }^{230}$ saw fit to vote with the conservative majority of the United States Supreme Court to strike down widely supported legislation like the Gun-Free School Zones Act of $1990^{231}$ and the Violence Against Women Act of 1994.232

When he was a United States Senator, Barack Obama declared that "the depth and breadth of [a candidate's] empathy" should be a factor in weighing her qualifications for judicial office. 233 When he became President and had to fill the first United States Supreme Court vacancy that arose during his presidency, his conservative opponents recalled his use of the word "empathy" and criticized him for it.

Obama has something specific in mind when he talks about empathy. He wants the justice's oath [". . . that I will faithfully and impartially discharge and perform all the duties ..."] to in effect be rewritten. Judges must administer justice with respect to persons, they must be partial to the poor, and so on. 234

These critics treated "empathic" as code for "liberal." 
But conservative justices, too, have bolstered their (conservative) decisions by professing empathy. In Gonzales v. Carhart, 235 the United States Supreme Court upheld the constitutionality of a federal statute prohibiting the medical procedure "dilation and evacuation" (so-called "partial birth" abortion), even though the Court had struck down an almost identical State prohibition seven years earlier in Stenberg v. Carhart. ${ }^{236}$ Both were 5-4 decisions, but because the pro-choice Justice O'Connor had been replaced by the anti-abortion Justice Alito, Justice Kennedy, who had dissented in Stenberg, found himself in the Gonzales majority and wrote the opinion of the Court. In that opinion, he upheld the federal prohibition partly in the name of empathy for the woman who comes to regret her abortion after the fact. ${ }^{237}$ And in Lawrence v. Texas, ${ }^{238}$ which declared unconstitutional a Texas statute making it a crime for two persons of the same sex to have sexual contact with each other, Justice Scalia, in his dissent, expressed empathy for those who are repelled by homosexuality and whose aversion is not shared by the "law-profession culture." 239

When President Barack Obama nominated Judge Sonia Sotomayor to the United States Supreme Court, conservative opponents of the nominee cited an injudicious speech she had delivered in 2001 in which she declared that a Latina judge, by virtue of her life experiences, would "more often than not reach a better conclusion [as a judge] than a white male" would. ${ }^{240}$ Former Republican Governor of Arkansas Mike Huckabee, reacting in 2009 to the news of this 2001 speech, stated, "If she is confirmed, then we need to take the blindfold off Lady Justice."241 If Governor Huckabee was suggesting that Lady Justice has always been blindfolded until now and, but for Sotomayor's nomination, would remain blindfolded, I would have to disagree. The holdings of conservative justices strongly suggest that the blindfold has come off before.

In every major case since he became the nation's seventeenth Chief Justice, Roberts has sided with the prosecution over the defendant, the state over the condemned, the executive branch over the legislative, and the corporate defendant over the individual plaintiff. 242

While it is not impossible that an ideologically detached justice would coincidentally favor the more powerful party - prosecution, the state, and the corporation - in each of these particular cases, the fact that the Chief Justice's positions have "served the interest, and reflected the values, of the contemporary Republican party" 243 powerfully suggests another explanation for his positions. The decisions of Justice Rehnquist also, after his first four years on the bench, were observed to produce ideologically predictable results:

(1) Conflicts between an individual and the government should, whenever possible, be resolved against the individual;

(2) Conflicts between state and federal authority ... should, wherever possible, be resolved in favor of the states; and

(3) Questions of the exercise of federal jurisdiction ... should, wherever possible, be resolved against such exercise. 244

In criticizing the conservatives' appropriation of "activism", "empathy", and ideology-based decisionmaking as betes noires in the process of judge-selection, I have relied on a type of fallacious argument known as Tu Quoque ("You do it yourself"). Not coincidentally (given the aim of this article), the speaker in Sonnet 121 falls into the same rhetorical trap. He responds to 
his traducers' accusations of licentiousness by accusing them of licentiousness. But such a response is not a logical refutation. It does not refute his traducers' explicit claim that he is licentious, nor does it refute their implicit claim that licentiousness is a bad thing. It simply says, "You, too." When conservatives criticize liberal judges for being "activist" and I respond by pointing out the "activism" of conservative judges, I have not refuted the conservatives' explicit claim that liberal judges are activist, nor have I refuted their implicit claim that "activist" is a bad thing for a judge to be. Still, my response of "you, too" is not wholly without point. It exposes the hypocrisy - or at least the disingenuousness - of their criticism. If activism per se were what disturbed the conservative critics, presumably the judges these critics admire - Justices Scalia and Thomas, for instance 245 - would not be activist. That these famously conservative judges are activist demonstrates that something else is disturbing these conservative critics. Presumably they object to activism on behalf of liberal causes but not to activism on behalf of conservative causes. The tu quoque criticism therefore rebuts the conservatives' claim to the moral high ground of judicial neutrality.

I have avoided using the word "neutral" until now, even though it is a word one often hears in this context, 246 because I am not altogether sure that true neutrality is attainable, or even desirable, unless we prefer judges who are not made of flesh and blood. At the time of this writing, the issue of same-sex marriage dominates much of the discussion about the judiciary's proper role, and when it came to light that a few gay people were on President Obama's short list of judicial candidates to fill the seat held by Justice Souter, some opponents of same-sex marriage complained that putting a gay judge on the bench would be "putting a vote for same-sex marriage on the highest court in the land." 247 This objection to gay candidates presupposes that a gay judge can be depended on to support same-sex marriage rights, and the objection is wrong-headed in two respects. First, some gay scholars oppose same-sex marriage. Paula Ettelbrick, for example, argues that "marriage runs contrary to two of the primary goals of the lesbian and gay movement: the affirmation of gay identity and culture and the validation of many forms of relationships." 248 A second and more serious flaw in this particular objection to gay judges is that the objection presupposes that heterosexual judges are neutral on issues relating to equality for gay people, as if gay people are the only ones who have sexual orientation. Heterosexual people can have strong predispositions about homosexuality, too. Had Justice Thurgood Marshall recused himself from Supreme Court cases involving discrimination against African-Americans, he would have been suggesting that white people are neutral on racial issues while people of color are not, as if white people have no race. As Martha Minow observed, "There is no neutrality, no escape from choice." 249 And if judges are necessarily choice-makers, making their choices on the basis of their outlooks, 250 perhaps consideration of a judicial candidate's personal perspective is not so misguided after all.

\section{Conclusion}

The mind that created King Lear and The Merchant of Venice was not dormant or in hiding when it produced the Sonnets. These lyric poems display the same powers of invention, the same penetrating insight into the human mind and heart, that have prompted legal scholars to turn to the plays for inspiration. The language of the Sonnets may be less immediately accessible than that of the plays, but the persevering, receptive scholar is sure to find in these poems elegant and provocative approaches to a host of legal problems. And, perhaps most important to me in my own line of work, the Sonnets bear out my admonition to skeptical students who complain that the difference between a condition precedent and a condition subsequent is merely a matter of words: "Words matter!"

${ }^{1}$ My title echoes the opening of one of William Wordsworth's sonnets (not one of my favorites, as it happens): 
Scorn not the Sonnet; Critic, you have frowned,

Mindless of its just honours; with this key

Shakespeare unlocked his heart; the melody

Of this small lute gave ease to Petrarch's wound;

William Wordsworth, "Scorn Not the Sonnet", in 2 Major British writers 108 (G.B. Harrison et al, eds. 1959) (1827).

${ }^{2}$ Almost as often, everyone loves to misquote him. How often have you heard - or perhaps even used - the phrase " gild the lily"? This is a misquotation of Shakespeare's King John. In Act Four, the Earl of Salisbury seeks to dissuade John, who has already been crowned once, from ordering a second coronation, on the ground that such a repetition would be "wasteful and ridiculous excess." Act 4, sc. 2, line 16. In advancing his argument, the earl offers John some other examples of excess, and among those examples we find:

To gild refinèd gold, to paint the lily. [line 11]

To paint a lily is a redundant act, since lilies are already brightly colored. To gild gold is a redundant act, since gold is already gilded. But a lily is not already gilded, so to gild a lily is not a redundant act but a potentially improving one. Thus, the correct phrase - correct as to both sense and literary accuracy - is "paint the lily."

${ }^{3}$ Professor Charles Fried provided a noteworthy exception to my observation. Charles Fried, Sonnet LXV and the " Black Ink" of the Framers 'Intention, 100 Harv. L. Rev. 751 (1987).

${ }^{4}$ Wordsworth expressed a view still popular today when he suggested that Shakespeare "unlocked his heart" in these Sonnets. See note 1, supra. Robert Browning replied mordantly to Wordsworth's suggestion, "If so, the less Shakespeare he," Robert Browning, "House", in 2 Major British Writers, supra note 1, at 575 (1874), and I tend to agree with Browning. Despite the tantalizing puns that Shakespeare's speaker makes on the name Will in Sonnets 135 and 136 and the elusive references in Sonnets 110 and 111 to the speaker's possible appearance on a public stage, I find in the Sonnets no foundation on which to construct even the most tentative anatomy of Shakespeare's inner life. I regard them not as confessions (except insofar as all art is perforce confessional) but as intellectual exercises undertaken for their own sake or perhaps to please friends or patrons.

5 Helen Vendler, The Art of Shakespeare's Sonnets 3 (1997).

${ }^{6}$ The mutation is often syntactical, as when Shakespeare puts a common word to uncommon use by altering its part of speech. In the first sonnet that I discuss in detail, Sonnet 35, Shakespeare uses the adjective "amiss" as a noun. (He does so in Sonnet 151 as well.) In sonnet 6, he transforms the adjective "happy" into a verb:

Which happies those that pay the willing loan.

And one of the most notable affectations of contemporary corporatespeak - using "task" as a verb - can actually boast a Shakespearean antecedent:

O! Lest the world should task you to recite [Sonnet 72].

This rhetorical device - altering a word's conventional part of speech - is known as anthimeria, and Shakespeare employs it frequently. In Hamlet's famous "To be or not to be" soliloquy, for example, we find these lines -

And thus the native hue of resolution

Is sicklied o'er with the pale cast of thought,

Hamlet, act 3, sc. 1, lines 83-84 (emphasis added) - where the adjective sickly has become a verb.

Sometimes in the Sonnets Shakespeare treats us to the conventional and unconventional use of the same word in a single line. In Sonnet 18: and in Sonnet 69:

And every fair [noun] from fair [adjective] sometime declines;

Thy outward [noun] thus with outward [adjective] praise is crown'd.

But occasionally he seems to lose control over his own virtuosity and goes too far in cleverness:

For as you were when first your eye I ey'd [Sonnet 104].

${ }^{7}$ This phrase is Helen Vendler's. Helen Vendler, supra note 5, at xiii.

8 Percy Bysshe Shelley, Ozymandias, in The Concise Columbia Book of Poetry 47 (William Harmon, ed., 1990). Shelley's sonnet offers a splendid example of ironic equivocation. Addressed to the ancient king's contemporaries, the words of the inscription warned of the futility of opposing him. Addressed to the poet's contemporaries, the inscription seems to warn of the futility of seeking a permanent glory. Thus, the king's own words have subverted themselves.

${ }^{9}$ These sentiments about the poet's art - sentiments that I have imputed somewhat fancifully to Shelley - were voiced quite explicitly by the Latin poet Horace more than 1,800 years before "Ozymandias" was written: "Exegi monumentum aere perennius" ("I have erected a monument more durable than bronze"). Horace, Book III, Ode XXX, in The Complete Odes and Satires of Horace 150 (Sidney Alexander, trans., Princeton Univ. Press 1999).

10William Wordsworth, "Nuns Fret Not at Their Convent's Narrow Room", in 2 Major British Writers, supra note 1, at 101 (1804). Unlike the Wordsworth sonnet that I quoted earlier, see supra note 1, this one is one of my favorites.

11 See supra note 4.

12George Orwell, 1984214 (Signet Books 1961) (1949).

${ }^{13}$ Letter to George and Thomas Keats, dated Dec. 22, 1817, in The Complete Poetical Works and Letters of John Keats 276-77 (Houghton Mifflin 1899). 
${ }^{14} I d$.

15 The delicacy and humor of Shakespeare's sympathy find many illustrations, but one of my favorites comes from Romeo and Juliet. Shortly after her first conversation with Romeo at a party, Juliet, obviously smitten, wants to find out who this young man is. But instead of coming right out and asking her gossipy nurse for the young man's name, Juliet slyly asks her for the names of two other men first, as if to suggest that her interest in the third-mentioned Romeo is merely the same idle curiosity that prompted her inquiries about the other two. Act 1, sc. 5, lines 128-35.

It is worth noting that fourteen of the consecutive lines spoken by Romeo and Juliet in their first conversation form a perfect Shakespearean sonnet, even though the lines are allocated between the two characters as seven separate speeches. Act 1, sc. 5, lines 93-106.

16 Deuteronomy says, "Justice, justice, thou shalt pursue." We are adjured to "pursue" it; "attainment" is not expected.

${ }^{17}$ The Merchant of Venice, Act 1, sc. 2, lines 80-83.

18 Helen Vendler, supra note 5, at xiv.

${ }^{19}$ Most of the lines in Shakespeare's Sonnets contain 10 syllables, ending in what is called a masculine rhyme (that is, a rhyme in which the final syllable is accented, such as "obey" and "delay"). Accordingly, a sonnet using only masculine rhymes would comprise 140 syllables. But Shakespeare occasionally employed feminine rhymes (that is, rhymes in which the final syllable is unaccented, such as "cherish" and "perish"), which add an eleventh syllable to each line containing such a rhyme. In Sonnet 20, for instance, every line ends with a feminine rhyme, so that sonnet comprises 154 syllables. In Sonnet 145, Shakespeare used tetrameter (8-syllable lines) instead of pentameter (10-syllable lines), so that sonnet comprises only 112 syllables. And Sonnet 126 confounds all expectations by consisting of only 12 lines instead of 14, some of which end in masculine rhymes and some in feminine.

${ }^{20}$ See, e.g., note 27 , infra.

21 "Accessary" and "accessory" are alternate spellings. The 1609 Quarto version of the Sonnets (the first published version of the complete Sonnets) uses the first spelling.

Shakespeare seems to have been familiar with English legal process. In the plays, as well, we find examples of terms of legal art used in surprising ways. In the opening scene of Othello, for instance, Iago uses the term "nonsuit" when he complains of being passed over for the position of Othello's second-in-command:

Three great ones of the city, In personal suit to make me his lieutenant, Off-capp'd to him: and, by the faith of man, I know my price, I am worth no worse a place: But he, as loving his own pride and purposes, Evades them, with a bombast circumstance Horribly stuff'd with epithets of war; And, in conclusion, Nonsuits my mediators ....

Othello, act 1, sc. 1, 8-16.

${ }^{22}$ I have mixed feelings about attaching line numbers to my presentation of each sonnet. As e.e. cummings's oeuvre famously illustrates, a reader's response to a poem can be affected by the impression it makes on her eye - a picture framed by the blank space bordering the page - and the presence of line numbers surely distorts that impression. I can only hope that their presence is justified in this instance by the resulting convenience in citation.

${ }^{23}$ Shakespeare uses the canker/sweetest-bud image in Sonnet 70 as well:

For canker vice the sweetest buds doth love.

${ }^{24}$ Shakespeare uses vowel rhyme in other sonnets, too. See, e.g., Sonnets 71, 106, and 145.

25 Reading this sonnet aloud reveals another aural oddity: the profusion of sibilants. The poem contains a total of forty-seven such sounds ( $s, x, z$, and soft $c$ ): fully one-third of the syllables. Every line in the poem contains at least one sibilant, and some contain as many as six:

Ex́cusing thy sins more than thy sins are.

And nine words in the poem contain two sibilants: Roses, eclipses, sweetest, trespass, Excusing, sins [twice], sense, accessary. This conspicuous deployment of sibilants is a poetic device known as sigmatism, a term derived from the Greek letter sigma (the Greek $s$ ). Since English is a rather sibilant language to begin with, sigmatism demands extraordinary frequency in order to be noticed at all. Wordsworth used this device in a passage about skating in his autobiographical poem The Prelude. And Shakespeare uses it in a number of his plays. In a famous passage in Hamlet , for example, sigmatism suggests the hissing of a snake:

The serpent that did sting thy father's life

Now wears his crown.

Act 1, sc. 5, lines 38-39. And in a soliloquy from King Henry the Fourth, Part Two in which the king complains of his inability to sleep, Shakespeare ingeniously uses a succession of $s t$ sounds, reminiscent of an old form of the traditional cry for silence:

And in the calmest and most stillest night. ...

Act 3, sc. 1, line 28. The sigmatism in Sonnet 35 may suggest the hissing noise that audiences at a melodrama direct at the villain (and that the speaker in the poem may be directing at himself). $C f$. Julius Caesar:

If the tag-rag people did not clap him and hiss him, according as he pleased and displeased them, as they use to do the players in the theatre, I am no true man. 
Act 1, scene 2, lines 258-61.

${ }^{26}$ Shakespeare uses salve as a verb meaning "soothe," as we would today in the phrase "salve one's conscience." And, as noted earlier, he uses amiss as a noun.

${ }^{27}$ I have remarked earlier upon Shakespeare's device of using the same word as two different parts of speech in the same line. See supra note 6 . Here, Shakespeare uses an entire phrase, thy sins, in two different senses in the same line, but the metamorphosis does not relate to part-of-speech but rather to grammatical case. The first thy sins is syntactically an object, while the second thy sins is syntactically a subject.

In the 1609 Quarto of the Sonnets, the word "their" appears in this line instead of the word "thy".

Excusing their sins more than their sins are.

Edward Capell, an eighteenth century Shakespearean critic and scholar, suggested that this was a misprint and that their ... their should be read as thy ... thy. Most contemporary scholars accept Capell's emendation. I lack the technical resources to make an independent editorial judgment, so I shall simply accept what these contemporary scholars have accepted. Capell's emendation certainly makes the line more sensible. If the correct words were their . . their, the only plausible antecedent for that pronoun would be All men (line 5), and I do not see why the speaker should feel specially ashamed of excusing the sins of all men.

This is as good a spot as any for saying a few words about punctuation. In the 1609 Quarto, the concluding punctuation mark in this sonnet is a comma, not a period. Obviously that was a misprint. Throughout this article I ignore the Quarto's punctuation, inasmuch as the Elizabethans and Jacobeans seem not to have established a set of punctuation rules comparable in their clarity and universality to our modern rules. Instead, I have studied the punctuation used in several modern editions of the Sonnets and followed the punctuation choices that seem to me best calculated to sustain my understanding of the poems.

28 In line 13, the speaker uses the word accessary.

${ }^{29}$ One of the most famous final couplets comes from Sonnet 116:

If this be error, and upon me prov'd,

I never writ, nor no man ever lov'd.

30I say "rarely" because a few other sonnets can be found in which the sestet is experienced as a unit: Sonnets 13 and 29 , for example.

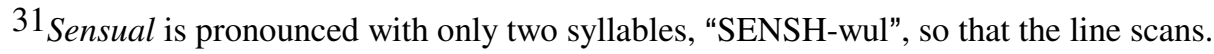

${ }^{32}$ The speaker in Sonnets 40, 41, and 42 identifies the beloved's misconduct precisely as sleeping with the speaker's mistress. The speaker in Sonnet 35 does not.

${ }^{33}$ When Shakespeare employs the same word as two different parts of speech in the same line - one part of speech being the conventional one, and the other being unconventional, see supra note 6 - the difference in such cases usually is only syntactical, not denotative. For example, in Sonnet 18 he uses "fair" as both an adjective (conventional syntax) and a noun (unconventional syntax), And every fair from fair sometime declines, but even in the unconventional syntax "fair" still denotes physical beauty. In Sonnet 35, on the other hand, Shakespeare employs the opposite device (line 9). He uses, each in its conventional syntax, two similar words having an identical etymology yet seemingly antithetic meanings (sensual and sense).

When the sonnet is read aloud, bring in sense sounds exactly like "bring incense," a pun that may call to readers' minds certain religious ceremonies associated with the forgiveness of sins. In view of the widespread anti-Catholic sentiment in Shakespeare's England, Shakespeare's readers may have had a more passionate reaction to the pun than we. To those readers, the bringing of incense might have suggested base, cowardly conduct: the making of a propitiatory offering to the injurer (the committer of the sensual fault) by the injured. For some astute - not to say audacious - speculations on Shakespeare's own association with Roman Catholicism, see Stephen Greenblatt, Will in the World (2004).

${ }^{34}$ Observe that the speaker in line 11 uses the single word myself rather than the two words My self that he used in line 7. Thus, his meaning in line 11 is that the defendant against whom he brings his plea is, simply, the speaker himself, without reference to the supposed "true 'Self.'" The 1609 quarto uses the two-word form in both lines, but I agree with those editors who use the two-word form in line 7 and the one-word form in line 11.

The speaker, by using the adjective lawful to modify plea but not to modify advocate in the previous line, suggests that he is using the adjective to mean something that applies to plea but not to advocate. If lawful were intended to mean "authorized by law," the adjective could have been used in both places with equal justification. Therefore, lawful signifies something else, and I suggest it means "justified" or "warranted." That is, the speaker suggests that his excuse-making conduct is worthy of condemnation and that he therefore acts justly when he enters a plea against himself. In King Henry the Sixth, Part Three, Queen Margaret uses the word "lawful" in what seem to be these two different senses: first "authorized" and then "justified." After Margaret's husband, King Henry the Sixth of England, is deposed by the Duke of York, Margaret flees to France to obtain the French king's aid in restoring Henry to the English throne.

Now, therefore, be it known... 


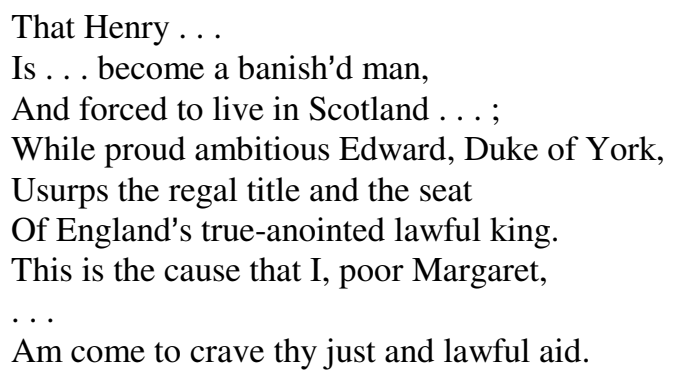

Act 3, scene 3, lines 23-32.

35 If we read sensual fault [line 9] to refer to a sexual betrayal such as the beloved's sleeping with the speaker's mistress, rob [bery] might also refer to that love-theft. And the adverb sourly means "with bitter result."

36 In a famous passage in the New Testament, Jesus says to one of the apostles, "[T]hou art Peter, and upon this rock I will build my church; and the gates of hell shall not prevail against it. And I will give unto thee the keys of the kingdom of heaven: and whatsoever thou shalt bind on earth shall be bound in heaven: and whatsoever thou shalt loose on earth shall be loosed in heaven." Matthew 16:18-19 (King James version). From this passage is derived the doctrine that Jesus directly transmitted his spiritual authority on earth to the apostle Peter during Jesus's lifetime and that each pope thereafter has succeeded to that authority by virtue of his election as pope.

37Robert Bolt, A Man for All Seasons 74, 98 (1960). The last of the three quoted sentences comes from a later scene but relates to the same issue and continues the image of an essential self.

Ironically, playwright Bolt puts into More's mouth words that strongly echo those spoken by More's adversary, Martin Luther, when confronting his Catholic accusers at the Diet of Worms: "Here I stand! I cannot do otherwise." (Of course, Luther's actual words were German: Hier stehe ich! Ich kann nicht anders.)

38Id. The historical Thomas More would strike us today as a bigot. Before More's break with King Henry the Eighth, More, in his official capacity as the King's chancellor, enthusiastically persecuted and burned Protestants as " heretics." Jasper Ridley, Henry VIII 142, 197-98 (1985).

${ }^{39}$ Id.

40398 U.S. 333 (1970). The opinion that was premised on statutory construction grounds was only a plurality opinion. Justice Harlan concurred in the judgment, but his reasons were constitutional, not statutory. Id. at 344-68 (Harlan, J., concurring).

41Universal Military Training and Service Act § 6(j), 50 U.S.C. App. § 456(j) (1964 ed., Supp. IV).

42398 U.S. at 337.

43 Id. at 340 .

${ }^{44}$ Id. at $342-43$.

45 See supra note 37.

46 See, e.g., In re Estate of Gerbing, 337 N.E.2d 29, 32-35 (1975).

47 See Jeffrey G. Sherman, Posthumous Meddling: An Instrumentalist Theory of Testamentary Restraints on Conjugal and Religious Choices, 1999 U. Ill. L. Rev. 1273, 1309-11 (1999).

${ }^{48}$ In this sonnet, and not for the last time, Shakespeare uses compare as a noun, meaning comparison. See note 65, infra. Again, this device is known as an anthimeria. See supra note 6.

${ }^{49}$ See, e.g., Terence Moore, Blind Loyalty to Vick Is Blind, Atlanta Journal-Constitution, Aug. 12, 2007, at 1E; David Whitley, Sacking Vick with a Rush to Judgment OK in This Case, Baltimore Sun, Aug. 22, 2007, at 2E.

50 Adam Liptak, Furor Ends in Deanship for Liberal Scholar, N.Y. Times, Sept. 18, 2007, at A16.

$51^{I}$.

52 Id.

53 See Francine D'Amico, Race-ing and Gendering the Military Closet, in Gay Rights, Military Wrongs: Political perspectives on Lesbians and Gays in the Military 3, 5 (Craig A. Rimmerman, ed., 1996) (hereinafter "Gays in the Military"). The longer, more official name for the new policy was "don't ask, don't tell, don't pursue." Id.

${ }^{54}$ Marine Col. Fred Peck, appearing as a witness before the United States Senate Armed Services Committee in a hearing dealing with the military's anti-gay ban, testified that he would not want his gay son to join the Marine Corps: not because he was afraid that his son's presence would interfere with morale or "unit cohesion" but because he was afraid that his son would be beaten up by the other Marines. 139 Cong. Rec. S. 8749, 103 ${ }^{\text {rd }}$ Cong., $1^{\text {st }}$ Sess., July 15 , 1993.

55 See David Ari Bianco, Echoes of Prejudice: The Debates Over Race and Sexuality in the Armed Forces, in Gays in the Military, supra note 53, at 47, 53.

56 Id. at 54.

${ }^{57}$ Randall Kennedy, The Marriage Struggle for Gay, Lesbian, and Black Liberation, 2005 Utah L. Rev. $781,789$. 
58 In 1922, the president of Harvard University, A. Lawrence Lowell, recommended that the university impose a quota on Jewish students as a way of reducing anti-Semitism on campus. See Jerry Kang, Negative Actions Against Asian Americans: The Internal Instability of Dworkin's Defense of Affirmative Action, 31 Harv. C.R.-C.L. L. Rev. 1, 40 n.188 (1996).

${ }^{59}$ See a letter from Colin Powell, then Chairman of the Joint Chiefs of Staff, to then Congresswoman Patricia Schroeder (D-Colo.), quoted in id. at 47. The African-American community is by no means unanimous in its rejection of the analogy between the barring of gay people from the military and the former barring of African-Americans from the military. Carl Rowan, an African-American journalist, wrote a column for the Chicago Sun-Times urging this very analogy as an argument against maintaining the anti-gay ban. Pointedly, he coupled a racist quote from a white Navy seaman in 1944 ("I'll be court-martialed before I'll take orders from a damn nigger") with a homophobic quote from a black Navy seaman in 1993 ("I'll quit the Navy before I'll serve on a ship with a known queer"). Carl T. Rowan, Issue of Justice Is Becoming Excuse for an Orgy of Hate, Chi. Sun-Times, May 14, 1993, at 43. It should also be noted that Professor Randall Kennedy, whom I cite approvingly on several occasions, see, e.g., supra note 57, is also

African-American.

${ }^{60}$ Regarding the canard as applied to gay people, see, for example, http://www.jesus-is-savior.com/Evils\%20in\%20America/Sodomy/pederasts.htm ("The homosexual activist movement and organized pedophiles are linked together by a common goal: To gain access to children for seduction into homosexuality."). Former Senator Sam Nunn (D-Ga.), as part of an effort to continue banning gay people from the military, "visited cramped showers and bathrooms to demonstrate how little privacy there is on an aircraft carrier or submarine, [thus reinforcing] one of the most widely held negative stereotypes of homosexuals: that gays are always promiscuous and allowing them to live in such close proximity to members of the same sex invites trouble." Editorial, Gay Rights Are Nonnegotiable, Chi. Sun-Times, May 14, 1993, at 41. Regarding the canard as applied to African-Americans, consider a speech delivered on the floor of the United States Senate in 1907 by Senator Ben Tillman (D.-S.C.) in support of the lynching of any Black man believed to have raped a white woman:

When stern and sad-faced white men put to death a creature in human form who has deflowered a white woman, they have avenged the greatest wrong, the blackest crime in all the category of crimes.... Look at our environment in the South, surrounded, and in a very large number of counties, outnumbered by the negroes - engulfed, as it were, in a black flood of semi-barbarians. ... Their minds are those of children, while they have the passions and strength of men.... [T] he white women of the South are in a state of siege....

41 Cong. Rec. 1441 (1907).

61Charles Moskos, Why Banning Homosexuals Still Makes Sense, Navy Times, Mar. 30, 1992, at 27.

62 See also Randall Kennedy, supra note 57, at 792.

Another reason given for rejecting the analogy between oppression of gay people and oppression of black people is the belief that homosexuality, unlike race, is a choice. Crystal Dixon, an administrator at the University of Toledo, wrote in a letter to the editor of the online edition of the Toledo (Ohio) Free Press:

I take great umbrage at the notion that those choosing the homosexual lifestyle are "civil rights victims." Here's why. I cannot wake up tomorrow and not be a black woman.

John Seewer (AP writer), Univ. Of Toledo Official Fired Over Column Sues, http://news.yahoo.com/s/ap/20081202/ap_on_re_us/column_controversy_1 (visited Dec. 4, 2008). Without bothering to refute Ms. Dixon's notion that homosexuality is a choice, I would point out that religion clearly is a choice, yet there is no doubt that discrimination on the basis of religion is "civil rights" discrimination. Professor Kennedy makes my point far more eloquently:

Racial oppression would not be one whit less dreadful and needful of judicial (and other forms of) intervention if blacks were somehow afforded the option of changing their color. ... [A]n appreciable number of blacks have complexions that allow them to be perceived as "white." But blacks who can " pass" should receive no less protection from racial oppression than "visible" blacks even though the former could, if they wished, blend in with the white majority. ... The ability of people to "pass," convert, retreat into a closet, or go underground should provide no basis for lessened attention to invidious discriminations.

Randall Kennedy, supra note 57, at 794.

${ }^{63}$ Clarence Page, Injustice Is Bigger Than Jena 6, Chi. Trib., Sept. 24, 2007, at 19.

${ }^{64}$ See Gloria Steinem, Why Women Are Never Front-Runners, N.Y. Times, Jan. 8, 2008, at A23. Ms. Steinem wrote, for example, "Black men were given the vote a half-century before women of any race were allowed to mark a ballot." Id. While that observation is undoubtedly true (in federal elections, at least), it hardly constitutes proof that women have suffered more discrimination than black men. After all, the number of women who were lynched for assertive behavior during that half-century was, I am quite confident, rather small. Conversely, when Barack Obama's erstwhile Chicago minister, the Reverend Jeremiah Wright, observed that "Hillary [Clinton] ain't never been called a ' nigger'," Obama Minister Under Scrutiny, Mar. 14, 2008, http://politicalticker.blogs.cnn.com/ (Visited Mar. 14, 2008), he was undoubtedly correct, but then I very much doubt that Barack Obama has ever been called a "cunt". 
${ }^{65}$ Sonnet 130, "My mistress' eyes are nothing like the sun," is best read as an ironic deflation of an imagined blazon. A blazon is a form of verse in which the poet catalogues his lady's physical excellences and praises them extravagantly. The blazon Shakespeare imagined might have begun with a line like "My mistress' eyes shine brightly as the sun;" and Shakespeare's speaker responds with pointed simplicity, "My mistress' eyes are nothing like the sun." And lest the reader mistake the speaker's remarks for loveless indifference, the speaker ends the sonnet with the following couplet:

And yet by heav'n I think my love as rare

As any she belied with false compare.

There's that noun compare again. And note that Shakespeare uses the pronoun she as a noun, meaning "woman."

${ }^{66}$ See, e.g., supra notes 6, 26.

${ }^{67}$ See supra note 6.

68 See Margaret Mitchell, Gone with the Wind 328, 365 (Warner Books 1999) (1936).

${ }^{69}$ See, e.g., http://www.americanpregnancy.org/labornbirth/birthingcenter.html (visited on January 23, 2008).

${ }^{70}$ Gary Bellow \& Bea Molton, The Lawyering Process (1978). I think the single word Lawyering would have been a more graceful title.

${ }^{71}$ The Oxford English Dictionary states that such use of "parent" as a verb is "rare before $20^{\text {th }}$ cent," and that the use of the gerund "parenting" is strictly of U.S. origin.

${ }^{72}$ Benjamin Spock, M.D. \& Michael B. Rothenberg, M.D., Baby and Child Care 1 (E.P. Dutton 1985) (1945).

${ }^{73}$ The term "breeder" is sometimes applied contemptuously by people without children to parents whose attitudes suggest that they feel entitled to special deference simply because they have managed to produce offspring.

${ }^{74}$ Joan Acocella, The Child Trip, New Yorker Magazine, Nov. 17, 2008, at 100, 100, reviewing two books on the subject of "hothouse parenting:" A Nation of Wimps: The High Cost of Invasive Parenting by Hara Estroff Marano, and Under Pressure: The New Movement Inspiring Us to Slow Down, Trust Our Instincts, and Enjoy Our Kids, by Carl Honoré.

${ }^{75}$ Comber v. United States, 584 A.2d 26, 42 (D.C. Ct. App. 1990); Girouard v. State, 583 A.2d 718, 721 (Md. 1991); State v. Maurico, 568 A.2d 879, 883 (N.J. 1990).

George Bernard Shaw applies this distinction more broadly:

If you strike a child, take care that you strike it in anger, even at the risk of maiming it for life. A blow in cold blood neither can nor should be forgiven.

George Bernard Shaw, Man and Superman, Maxims for Revolutionists (1903).

76 Joshua Dressler, Understanding Criminal Law 571 (4th ed. 2006).

${ }^{77}$ Maher v. People, 10 Mich. 212, 220 (1862) (emphasis omitted).

78 Joshua Dressler, Why Keep the Provocation Defense?: Some Reflections on a Difficult Subject, 86 Minn. L. Rev. 959, 973 (2002) (footnote omitted).

${ }^{79}$ Premeditated homicide is probably the classic kind of homicide that cannot be mitigated by proof of adequate provocation; it is murder in the first degree. George Fletcher, Rethinking Criminal Law 253 (1978).

${ }^{80}$ Such discovery is perhaps the paradigmatic example of an adequate provocation. See Joshua Dressler, supra note 76 , at $572-73$.

81 John Milton, Paradise Lost Book 1, in Paradise Lost and Other Poems, 97, 100 (Maurice Kelley, ed., Walter J. Black, Inc. 1943). To say that these sentiments are Milton's is somewhat misleading. True, Milton wrote these words, but he put them into the mouth of Satan. And he has Satan remark, somewhat inconsistently and only a few lines later: Better to reign in hell, than serve in heaven.

Id. at 100 .

82 The Model Rules of Professional Conduct, dealing with public service, expect an attorney ordinarily to be willing to undertake such representation:

A lawyer shall not seek to avoid appointment by a tribunal to represent a person except for good cause, such as . .

. (c) the client or the cause is so repugnant to the lawyer as to be likely to impair the client-lawyer relationship or

the lawyer's ability to represent the client.

ABA Model Rules of Professional Conduct, Rule 6.2.

${ }^{83}$ Steven Keeva, Why Lawyers Lose in Love, 91 A.B.A.J. 76 (2005).

${ }^{84}$ In today's parlance, the word "mistress" generally connotes vice. It is often applied to the steady female sexual partner of a married man to whom she is not married, especially when she receives financial support from him. In the Sonnets, on the other hand, Shakespeare's speaker uses the word "mistress" the way we might use the word "sweetheart ": a woman who is being courted. See, e.g., Sonnets 127 and 130.

85 The sequence begins with Sonnet 127: "In the old age black was not counted fair."

86 "True" as a synonym for "sexually faithful" is not entirely archaic. Even today, we speak of being true to one's spouse, and the very word "betrothal" has truth as its root.

${ }^{87}$ Lorenz Hart acknowledged this possibility in his sardonic lyrics for one of the best-known songs in the Rodgers 
\& Hart canon:

The furtive sigh,

The blackened eye,

The words "I'll love you till the day I die,"

The self-deception that believes the lie -

I wish I were in love again.

Lorenz Hart, I Wish I Were in Love Again, in The Complete Lyrics of Lorenz Hart 228 (Dorothy Hart \& Robert Kimball, eds., Alfred A. Knopf 1986) (1937).

${ }^{88}$ The speaker could easily have said "Ignorant of the world's false subtleties" instead of Unlearnèd in the world's false subtleties. Both lines scan properly in iambic pentameter.

${ }^{89}$ Vainly certainly means "futilely", as in the phrase "struggling vainly." But vainly can also mean "conceitedly" or " arrogantly", so the speaker's choice of this particular adverb also suggests that the speaker's vanity - vanity as to his youthful appearance and demeanor or vanity as to the skill of his imposture - may underlie this self-deception.

${ }^{90}$ The speaker certainly could have been more direct. "Although she knows full well that I am old" could have replaced the language of line 6 and still fitted the requirements of iambic pentameter.

The negative adjectives that the speaker uses earlier to describe the spurious self he strove to present - untutored and unlearnèd - might themselves be characterized as litotes, albeit compressed ones.

${ }^{91}$ Doris Kearns Goodwin, No Ordinary Time 133 (1994).

${ }^{92}$ See William Shakespeare, As You Like It act 2, sc. 7, line 120.

${ }^{93} \mathrm{My}$ favorite litotes comes from a story by Saki (H.H. Munro). He wrote a series of fictional sketches about one Reginald: a vain, foppish, indolent young man without any scruples. His remarks during a conversation with a duchess prompted her to reflect that "Reginald did not exceed the ethical standard which circumstances demanded." H.H. Monro, Reginald at the Theatre, in The Short Stories of Saki 7, 7 (Viking Press 1958) (1904).

${ }^{94}$ Oscar Wilde had some fun illustrating what Coleridge, writing quite seriously, called the willing suspension of disbelief. In this scene from The Importance of Being Earnest, a distrustful Gwendolen puts a question to her fiancé:

Gwendolen. Mr. Worthing, what explanation can you offer to me for pretending to have a brother?

Was it in order that you might have an opportunity of coming up to town to see me as often as possible?

Jack. Can you doubt it, Miss Fairfax?

Gwendolen. I have the gravest doubts upon the subject. But I intend to crush them.

Oscar Wilde, The Importance of Being Earnest, in Plays of Oscar Wilde 247, 301 (Penguin 1982) (1895).

95 Songwriter Stephen Sondheim illustrated the malleability of the word simple in a song from his musical comedy A Little Night Music. Fredrik, a middle-aged widower, has married a woman who is too young and untutor'd for him. (Indeed, she has refused to let him consummate the marriage.) In a duet with his former mistress, Desirée, he

cluelessly catalogues for her what he wants to suppose are his new wife's excellent qualities, but Desirée is not fooled.

[Fredrik]

She dotes on--

[Desirée] Your dimple! [Fredrik]

My snoring.

[Desirée]

How dear. [Fredrik] The point is, she's really simple. [Desirée] Yes, that much seems clear.

Stephen Sondheim, A Little Night Music, in Best American Plays, $8^{\text {th }}$ Series 182, 198-99 (Clive Barnes, ed. 1983) (1973).

96 [H] abit has at least two possible meanings in line 11. It might mean "customary behavior", in which case the line suggests that lovers are best off conducting themselves as if they trusted each other. Or it might mean "apparel", in which case the line suggests that lovers are best off wearing a costume (assuming a disguise) of apparent trust.

Line 11 also contains the word seeming. The speaker in this sonnet takes a tolerant view of "seeming": more tolerant than, say, Hamlet.

Seems, madam? Nay, it is. I know not "seems".

William Shakespeare, Hamlet, Act 1, sc. 2, line 76.

97 See supra note 6.

98 In line 1 , love is a noun meaning "lover" or "beloved". In line 11 , it is a noun referring to the emotion love. In line 12 , the first love is a noun referring to people who are in love, and the second love is a verb.

The use of the same word in more than one of its possible senses is a figure of speech called an antanaclasis. Shakespeare used the device frequently: in Othello, for instance, where Othello says

Put out the light and then put out the light.

Othello, act 5, sc. 2, line 7. The first light means "illumination", while the second light means "Desdemona's life". While antanaclasis can be employed seriously, as in Othello, it is perhaps more often employed comically: as a pun. History credits Benjamin Franklin with an antanaclasis uttered at the signing of the Declaration of Independence: "We must all hang together, or assuredly we shall all hang separately." John Bartlett, Bartlett's Familiar Quotations 320 
(Justin Kaplan, ed., Little, Brown \& Co., 17th ed. 2002) (italics added). And the final couplet in Shakespeare's Sonnet 138 turns on an antanaclasis involving the word lie: meaning both "speak falsely" and "engage in sexual intercourse."

${ }^{99}$ Many artists before and since Shakespeare have observed that lies often make life more liveable, but their observations are generally made in a censorious, or at least regretful, spirit. In Henrik Ibsen's play The Wild Duck, on the other hand, a rather cynical doctor declares with bitter certitude, "I try to discover the Basic Lie - the pet illusion that makes life possible; and then I foster it. . . Rob the average man of his basic lie and you rob him of his happiness as well." Henrik Ibsen, The Wild Duck 103, 194, 195 (Modern Library; Eva Le Gallienne, trans. 1961) (1884). What makes the sonnet's speaker's declaration so different from the doctor's is the composure with which the speaker expresses it.

${ }^{100}$ See Helen Vendler, supra note 5, at 587. 